\title{
Hydraulic fracturing flowback chemical composition diversity as a factor determining possibilities of its management
}

\author{
Joanna Fajfer ${ }^{1} \cdot$ Olga Lipińska $^{1}$ (D) Monika Konieczyńska ${ }^{1}$ \\ Received: 6 August 2020 / Accepted: 5 September 2021 / Published online: 13 October 2021 \\ (C) The Author(s) 2021
}

\begin{abstract}
The chemical characteristic of flowback fluid from hydraulic fracturing for shale gas exploration/production in various localizations is presented. The results of statistical analysis have shown that variability in the chemical composition of these fluids is statistically significant and depends on the time difference between fracturing process and flowback sampling as well as sampling spot within the installation for flowback collection. Parameters which depend on sampling schedule (time and spot of sampling) are as follows: electrical conductivity and concentration of ammonia, boron, barium, calcium, lithium, sodium, magnesium, manganese, sodium, strontium, silicate, bromide, and chloride. Independent parameters are $\mathrm{pH}$, total organic carbon (TOC), concentration of potassium, and iron. The ranges of the values of the characteristic parameters were determined, taking into account the representativeness of the samples, supported by statistical tests. The methods for the reuse of flowback fluids in terms of chemical composition are presented.
\end{abstract}

Keywords Flowback fluid $\cdot$ Hydraulic fracturing $\cdot$ Management of flowback fluid

\section{Introduction}

The common method used for exploration and exploitation of unconventional hydrocarbons (tight gas, shale gas, tight oil) is hydraulic fracturing of the reservoir rock through horizontal borehole. Hydraulic fracturing increases hydrocarbon inflow from reservoir rock by making small fractures and increasing reservoir permeability (Fajfer et al. 2016; Oetjen et al. 2017). The method rests on pumping a large amount of fracturing fluid into the reservoir. A high pump rate $\left(6-20 \mathrm{~m}^{3} / \mathrm{min}\right)$ allows achieving high pressure up to $100 \mathrm{MPa}$ on the inlet to the well (Steliga and Uliasz 2012; Pakulska 2015). After the fracturing process, part of the fluid returns from the well to the

Responsible Editor: Philippe Garrigues

Olga Lipińska oant@pgi.gov.pl

Joanna Fajfer

jfaj@pgi.gov.pl

Monika Konieczyńska

mkon@pgi.gov.pl

1 Polish Geological Institute - National Research Institute, Rakowiecka 4, 00-975 Warsaw, Poland surface as a so-called flowback. Fracturing fluid is a water solution of various chemicals with a weight concentration from 0.5 to 2.5\% (Fajfer et al. 2016; Pakulska 2015; Krogulec and Sawicka 2012; U.S. EPA 2016). The composition of those chemicals is adjusted to the physicochemical parameters of the reservoir. During the fracturing process, the composition of the fracturing fluid is modified according to the process stage. Physicochemical parameters of fluid flowing back to the surface depend on parameters of fracturing fluids used during the process, physicochemical properties of reservoir rocks, and formation water. Additionally, the parameters of flowback fluid depend on duration time and temperature of reaction between fracturing fluid and reservoir rock. The amount of flowback fluid depends on pressures of fluid in the reservoir, amount of reservoir water, and collection time. The flowback fluid is collected during production tests lasting several weeks. After a production well head is installed in the production phase, all fluids that come up together with hydrocarbons are called produced water, though their characteristics can still remain very similar to former flowback and they still need to be managed in a similar way.

The fracturing process consumes a large amount of water. Data collected in different countries and at different stages of exploration/exploitation presents the amount of water per one well that varies between 7500 and $38,000 \mathrm{~m}^{3}$ in the USA 
(Kuwayama et al. 2015; Vengosh et al. 2014), 2000 and $77,000 \mathrm{~m}^{3}$ in Canada (Jacobsen and Gravesen 2016), 10,000 and $30,000 \mathrm{~m}^{3}$ in the UK (Hammond et al. 2015; Stumford and Azapagic 2014), and $12,095 \mathrm{~m}^{3}$ in Germany (Olsson et al. 2013; Bergman 2014). In Poland, where hydraulic fracturing was performed only for the hydrocarbon exploration stage, the amount of used water varied between 1284 and $37,849 \mathrm{~m}^{3}$. After fracturing job stops, flowback fluid flows back through open valve on the head of a borehole (Konieczyńska et al. 2015). A large portion of the fluid is collected in the first days after fracturing which is a result of pressure equilibration in reservoir (U.S. EPA 2016). However, during the further exploitation stage, it keeps flowing back together with reservoir water as so-called produced water. It is reported that in the USA, the amount of recovered fluid varied between 10 and $80 \%$ of fluid pumped into a borehole (U.S. EPA 2016; Harrison et al. 2014; Olmstead et al. 2013; Haluszczak et al. 2014). In Europe, flowback fluid was collected only during reservoir tests in the exploration stage as so far no production from unconventional reservoirs has been started. The amount of collected fluid in Germany varied between 10 and 30\% of fluid used for fracturing. In Poland, the amount varied between 16 and 30\% (Konieczyńska et al. 2015). The flowback fluid contains a lot of chemicals that can pose a significant threat to the environment. Therefore, it is recommended to reuse this fluid for the preparation of another portion of fracturing fluid. However, if there is no possibility to reuse the flowback, it should be treated as waste. The appropriate treatment processes are needed in order to reach the required physicochemical parameters for flowback fluid reuse or its safe disposal.

The aim of the study is to find physicochemical parameters of flowback fluid that are crucial for the development and application of appropriate treatment processes. Because the chemical composition of flowback fluid changes along recovery time, the treatment process should be independent of variability of the physicochemical parameters and should be effective in a broad range of their values. The study was performed based on chemical and physical analyses of flowback fluids from the USA, Canada, Germany, and the UK as well as from Poland. The chemical and physical analyses of flowback fluids in Poland were performed by the Polish Geological Institute-National Research Institute (PGI-NRI) between 2010 and 2016. The statistical methods were applied for the comparison of the results of the analysis. The discussion on the results was presented in the light of waste management.

\section{Geological settings}

The Americans have the greatest experience in the field of exploration and exploitation of unconventional hydrocarbons, where natural gas and crude oil from shale formations have been extracted since the early 90s (Curtis 2002). In Canada, exploration and exploitation of shale gas and oil started in 2005, from Montney Formation, and in 2007, from the Horn River formation (Rivard et al. 2014). However, the highest rate of development is observed in China, where the exploration started in 2005 , the first exploitation tests were performed in 2008 , and the first concessions for unconventional hydrocarbons production were issued in 2009 (Zhou et al. 2016). In Europe, only exploration tests have been performed, mainly in Poland where 72 localizations were tested (Ministry of the Environment 2016). Several tests were performed in Germany (Olsson et al. 2013; Bergman et al. 2014) and the UK (Pripch et al. 2015; Hudson et al. 2016). In Poland, the reservoir tests indicated low effectiveness of hydrocarbons recovery, and further exploration of unconventional hydrocarbons was ceased. In the UK, fracturing of reservoirs induced seismic activities, and thus, further exploration involving hydraulic fracturing was banned (Hammond et al. 2015).

Shale gas formations differ from each other by geological conditions, depth and thickness, organic carbon and clay content, thermal maturity, and so on. Therefore, the chemical composition and amount of fracturing fluid pumped into reservoir in each borehole are tailored to local geological conditions.

In the USA, the prospective shale gas and oil formations are located in, Texas, Oklahoma, Arkansas, and Pennsylvania (Curtis 2002; Jarvie 2012).

Those locations encompass the following geological formations: Haynesville (Upper Jurassic), Barnett (Lower Carboniferous), Marcellus (Middle Devonian), Fayetteville (Lower Carboniferous), Eagle Ford (Upper Cretaceous), and Woodford (Devonian). The depth of the reservoir depends on the location - the shallowest is Marcellus - the upper boundary is located between 1200 and 2,400 m below the surface, whereas the deepest is Haynesville formation - with the upper boundary between 3200 and $4100 \mathrm{~m}$. The average thickness of reservoirs is around $45 \mathrm{~m}$ for Woodford and Marcellus and up to $200 \mathrm{~m}$ in the case of Barnett. Average organic matter content for shale formations varies between 1.3 and $5 \%$, whereas thermal maturity from 1.2 to $1.6 \%$ Ro (vitrinite reflectance scale) (Poprawa 2010a; Janas and Dyrka 2013).

Formations with shale gas potential in Canada are located mainly in two provinces: British Columbia (upper Devonian Horn River and Muskwa formations, and lower Triassic formation Montney) and Alberta (upper Devonian Duvernay and lower Triassic Montney formations). The top of upper Devonian formations in British Columbia is located up to $2500 \mathrm{~m}$ below surface, and their thickness varies between 200 and $500 \mathrm{~m}$. The organic matter content is up to $6 \%$. The top of the Montney Formation lies between 500 and $4000 \mathrm{~m}$ of depth, with its maximum thickness of 300-400 $\mathrm{m}$ and organic matter content between 0.1 and $3.6 \%$ (the average $0.8 \%$ ). The Muskwa Shale deposition in northwest Alberta is the northern 
continuation of the Duvernay Shale in central Alberta. Its top is located at $1000 \mathrm{~m}$ below the surface in the Eastern part and reaches $5500 \mathrm{~m}$ in the Western part. The thickness varies between 30 and $120 \mathrm{~m}$ and organic matter content between 0.1 and $11.1 \%$ (Rivard et al. 2014).

The Sichuan and the Tarim basins are reservoirs with the biggest shale gas potential in China (Changbo and Pieńkowski 2015). They are located deeper than in the USA and have a more complex geological structure (Changbo and Pieńkowski 2015). In the Sichuan basin, the gas exploitation is conducted in four regions of the Longmaxi shale formation: Fuling, Changning, Weiyuan, and Pengshui. The thickness of the formation varies between 100 and $120 \mathrm{~m}$; however, the layers rich in gas are located at the bottom of the formation, and their thickness is around $30 \mathrm{~m}$. The top of the formation is located between 2000 (in the Pengshui part) and $4500 \mathrm{~m}$ (Yang 2019). Organic matter content is above $2 \%$ and thermal maturity above 2.2\% Ro (Changbo and Pieńkowski 2015).

In Germany, Lower Jurassic Posidonia Shale with 8\% content of organic matter is considered as most prospective shale gas formation. It is a part of the Lower Saxonian Basin located $3000 \mathrm{~m}$ below the surface. The thickness of the formation varies between 15 and $30 \mathrm{~m}$ (Janas and Dyrka 2013).

In the UK, there are three shale formations with shale gas potential: two Carboniferous - Bowland in Northern England and Midland Valley in Scotland (Monaghan 2014), and the Jurassic one - Weald in southeastern England (Stephenson 2015; Hammond et al. 2015). The content of organic matter in Bowland formation varies between 2 and $5 \%$, and its thermal maturity of $1.2 \%$ Ro is higher than the thermal maturity of shale from Weald formation which is only 0.8\% Ro (Janas and Dyrka 2013).

In Poland, unconventional hydrocarbons are expected in fine-grain deposits of lower Paleozoic (upper Ordovician and lower Silurian shales) located in the Baltic and the Lublin Basins. In the Baltic Basin, the deposits are located between $1000 \mathrm{~m}$ below the surface in the Eastern part and $4500 \mathrm{~m}$ below the surface in the Western part (Poprawa 2010b; Karcz et al. 2013). Those formations are less permeable than conventional hydrocarbons deposits (Dyrka 2013) with thermal maturity which varies from 0.5 to $4 \%$ Ro in the Baltic Basin and from 0.6 to $2 \%$ Ro in the Lublin Basin. In the Baltic Basin, deposits contain from less than 1 to $2.5 \%$ of organic matter, whereas in the Lublin Basin from less than 1 to $3 \%$ (Poprawa 2010b).

\section{Chemical characteristic of flowback fluids from worldwide locations}

According to literature data, in the USA, the amount of flowback fluid and produced water from one borehole is in the range from 10 to $80 \%$ of fracturing fluid volume injected during the hydraulic fracturing process (U.S. EPA 2016;
Harrison et al. 2014; Olmstead 2013; Haluszczak et al. 2013). In the first month, the average amount of fluid that returns to the surface is in the range of 8 to $10 \%$ (Olsson et al. 2013). After 6 months, the flowback volume is in the range from 20 to $50 \%$ (Kondash et al. 2017). In Canada, the amount of flowback fluid that returns after the fracturing process is in the range from 10 to $30 \%$ of injected volume (Bustin et al. 2018), whereas in the Sichuan Basin in China, the amount is in the range from 10 to $60 \%$ (Yang et al. 2019). In the case of Europe, hydraulic fracturing was performed only for exploration purposes; thus, produced water was not collected. In Poland, the amount of the collected flowback was in the range from 16 to $30 \%$ of injected fluid volume (Konieczyńska et al. 2015; Fajfer et al. 2016), whereas in Germany, this amount was around 25\% (Olsson et al. 2013).

The scope of physicochemical analysis of flowback fluid reported in the literature is very diverse (He et al. 2013; Hayes 2012; Olsson et al. 2013; Yang 2019; Konieczyńska et al. 2011; Konieczyńska et al. 2015; Owen 2017; Owen and Bustin 2017; Liang et al. 2018; Busby 2018; EA 2011; Zolfaghari et al. 2015). Total dissolved solids concentration (TDS), $\mathrm{pH}$, concentration of sodium, potassium, calcium, barium, strontium, iron, chloride, bromide, and sulfate are the most frequently reported in the literature. The data on electrochemical conductivity and total organic carbon content (TOC) are less common. Biological oxygen demand (BOD) and chemical oxygen demand (COD) are presented occasionally. Among the remaining parameters, the concentration of lead, chromium, zinc, and nickel was most often determined.

The biggest dataset of chemical analysis results reported in the literature is related to flowback fluids from Marcellus and Barnett deposits (Fig. 1). Despite different chemical compositions, it has been found, on the basis of nineteen samples from Marcellus and five samples from Barnett, that the main constituent is chloride (Hayes 2012). Flowback fluids were characterized by $\mathrm{pH}$ within range from 4.9 to 7.9 and TDS from 680 to $261,000 \mathrm{mg} / \mathrm{l}$ (increasing with time of recovery). The hardness of the fluid varied between 630 and 95,000 $\mathrm{mgCaCO}_{3} / 1$, whereas COD and BOD from 228 to 1900 $\mathrm{mgO}_{2} / 1$ and from 2.8 to $2070 \mathrm{mgO}_{2} / 1$, respectively. The concentration of chloride and sulfate was within range from 64.2 to $181,000 \mathrm{mg} / \mathrm{l}$ and from 10.3 to $348 \mathrm{mg} / \mathrm{l}$, respectively. The concentration of sulfate was dropping down with an increase of collected flowback fluid. The concentration of bromide ranged from 35.5 to $1600 \mathrm{mg} / 1$. Concentrations of other constituents were as follows: sodium from 63.8 to $75,800 \mathrm{mg} / \mathrm{l}$, calcium from 35.2 to $24,000 \mathrm{mg} / \mathrm{l}$, potassium from 2.69 to $3950 \mathrm{mg} / \mathrm{l}$, barium from 0.332 to $4220 \mathrm{mg} / \mathrm{l}$, strontium from 0.58 to $8020 \mathrm{mg} / \mathrm{l}$, and iron from 2.68 to $158 \mathrm{mg} / \mathrm{l}$ (Hayes 2012). In case of flowback fluids from Barnett deposit, $\mathrm{pH}$ value ranged from 6.5 to 8.0 , TDS from 5850 to $97,800 \mathrm{mg} / 1$, hardness from 840 to $21,000 \mathrm{mgCaCO}_{3} / \mathrm{l}, \mathrm{COD}$ from 850 to $4280 \mathrm{mgO}_{2} / 1$, BOD from 89 to $2120 \mathrm{mgO} / 1$, and TOC from 


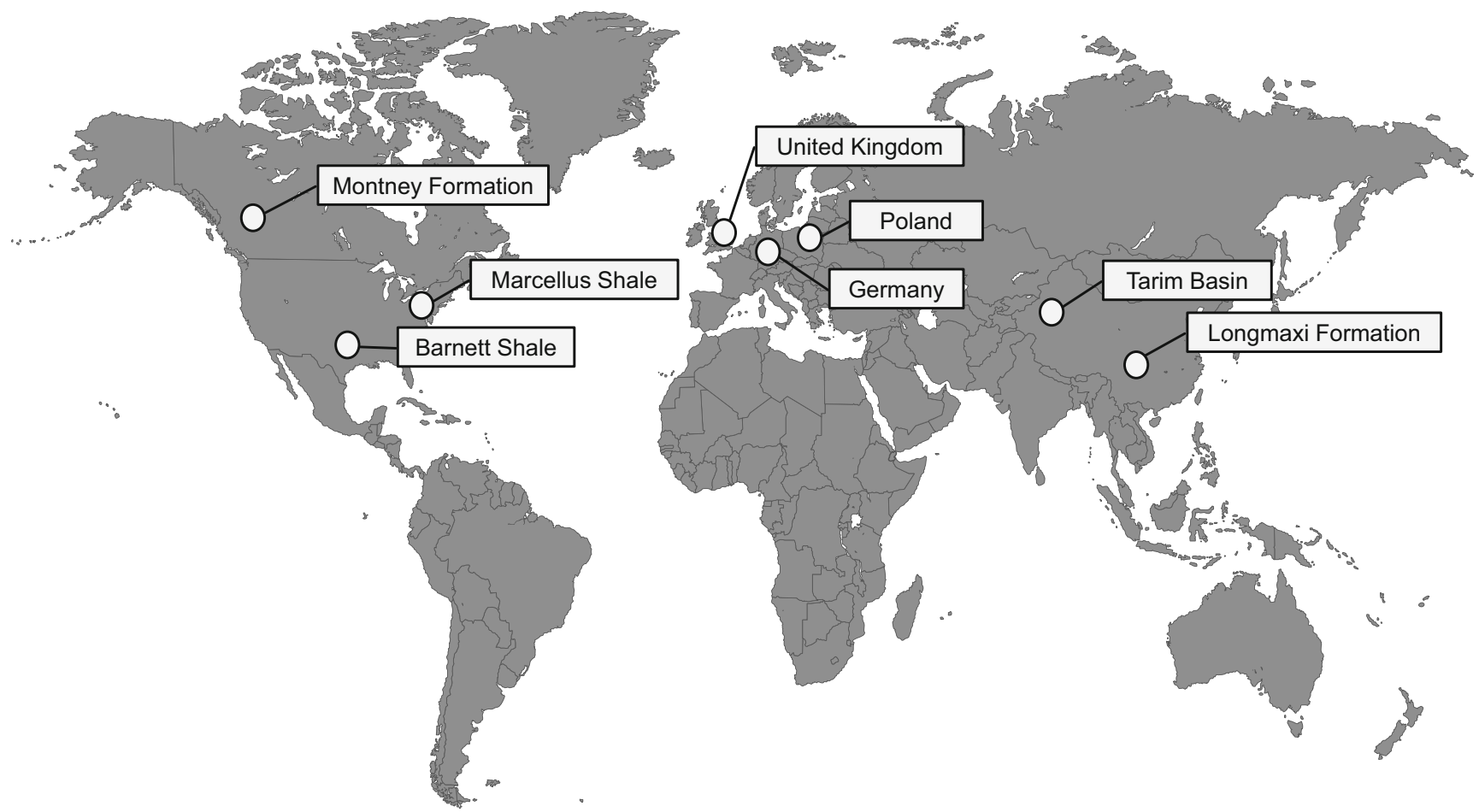

Fig. 1 Worldwide locations of shale gas sites with available chemical characteristics of flowback fluids

6.2 to $99.1 \mathrm{mg} / \mathrm{l}$. Concentration of chloride was within range from 3300 to $60,800 \mathrm{mg} / \mathrm{l}$, sulfate from 120 to $1260 \mathrm{mg} / \mathrm{l}$, bromide from 34.3 to $798 \mathrm{mg} / \mathrm{l}$, sodium from 278 to 28,200 $\mathrm{mg} / \mathrm{l}$, calcium from 13 to $6730 \mathrm{mg} / \mathrm{l}$, potassium from 4 to 750 $\mathrm{mg} / \mathrm{l}$, barium from 0.053 to $17.9 \mathrm{mg} / \mathrm{l}$, strontium up to 1550 $\mathrm{mg} / \mathrm{l}$, and iron up to $93.8 \mathrm{mg} / \mathrm{l}$. Other elements were present in fluids from both deposits at trace level (Hayes 2012).

In Canada, the flowback fluids from thirty-one boreholes in Montney Formation were analyzed (Owen et al. 2017, Bustin et al. 2018)(Fig. 1). The electrical conductivity of the fluids ranged from 15 to $200 \mathrm{mS} / \mathrm{cm}$ and $\mathrm{pH}$ from 2.3 to 9.5 . TDS was within range from 3609 to $228,259 \mathrm{mg} / \mathrm{l}$; however, an increase of TDS along the time of fluid recovery was observed. Similar to the USA boreholes, the main constituent in flowback fluid from Canadian boreholes was chloride, with concentrations from 1893 to $164,018 \mathrm{mg} / \mathrm{l}$. Concentration of sulfate ranged from 0.1 to $1084 \mathrm{mg} / \mathrm{l}$, sodium from 1344 to $51,027 \mathrm{mg} / \mathrm{l}$, calcium from 13 to $11,705 \mathrm{mg} / \mathrm{l}$, potassium from 49 to $1920 \mathrm{mg} / \mathrm{l}$, magnesium from 9 to $1329 \mathrm{mg} / \mathrm{l}$, barium from 1 to $467 \mathrm{mg} / \mathrm{l}$, strontium from 4 to $1219 \mathrm{mg} / \mathrm{l}$, and lithium from 1 to $49 \mathrm{mg} / \mathrm{l}($ Owen 2017).

Chinese studies concerned flowback fluids from boreholes in the Longmaxi shale formations of the Sichuan Basin (Yang et al. 2019) and from the Tarim Basin (Liang et al. 2018)(Fig. 1). The Sichuan Basin flowback fluids were collected from six boreholes. Measured TDS ranged from 13,000 to $55,000 \mathrm{mg} / 1$ and $\mathrm{pH}$ value from 6.84 to 7.48 . Concentration of other constituents varied as follows: chloride from 13,110 to 36,470 $\mathrm{mg} / \mathrm{l}$, bicarbonate from 310 to $1263 \mathrm{mg} / \mathrm{l}$, bromide from 180 to $470 \mathrm{mg} / \mathrm{l}$, sulfate from 41 to $172 \mathrm{mg} / \mathrm{l}$, sodium from 8296 to $19,830 \mathrm{mg} / \mathrm{l}$, calcium from 564 to $3870 \mathrm{mg} / \mathrm{l}$, potassium from 157 to $768 \mathrm{mg} / \mathrm{l}$, barium from 138 to $412 \mathrm{mg} / \mathrm{l}$, magnesium from 105 to $336 \mathrm{mg} / \mathrm{l}$, and strontium from 67 to $320 \mathrm{mg} / \mathrm{l}$. Concentrations of ammonia, aluminum, and iron were at trace level, or those species were not detected in samples of investigated flowback fluids (Yang et al. 2019). In the Tarim Basin, samples of flowback fluid were collected from one borehole, and only fluid density, $\mathrm{pH}$, and concentration of chloride were tested. Density ranged from 1.088 to $1.22 \mathrm{~g} / \mathrm{cm}^{3}$, pH was determined between 5.86 and 6.71 , and chloride concentration varied between 32,000 and $64,000 \mathrm{mg} / \mathrm{l}$; but the maximum was measured after 6 days of recovery, and it decreased in the next days (Liang et al. 2018).

In Germany, the flowback fluid from the Dahmn-3 borehole was tested (Fig. 1). Similar to fluids from boreholes in Canada and the USA, the highest concentration was observed for chloride from 40,360 to $88,440 \mathrm{mg} / \mathrm{l}$. Other constituents were present at lower concentrations: sodium from 17,690 to $36,390 \mathrm{mg} / \mathrm{l}$, calcium from 6700 to $16,550 \mathrm{mg} / \mathrm{l}$, strontium from 790 to $1720 \mathrm{mg} / \mathrm{l}$, barium from 180 to $593 \mathrm{mg} / \mathrm{l}$, magnesium from 890 to $2130 \mathrm{mg} / \mathrm{l}$, potassium from 52 to $570 \mathrm{mg} /$ 1 , and iron from 23 to $160 \mathrm{mg} / 1$. Other metals were present at trace concentrations. The concentration of sulfate ranged between 4 and $15 \mathrm{mg} / \mathrm{l}$. Data related to $\mathrm{pH}$ value, TDS, and TOC were not reported (Olsson et al. 2013).

In the case of the UK, the chemical analyses of twenty-four parameters were performed for fracturing fluid from Prees Hall 1 borehole located in the Lancashire County (Fig. 1). 

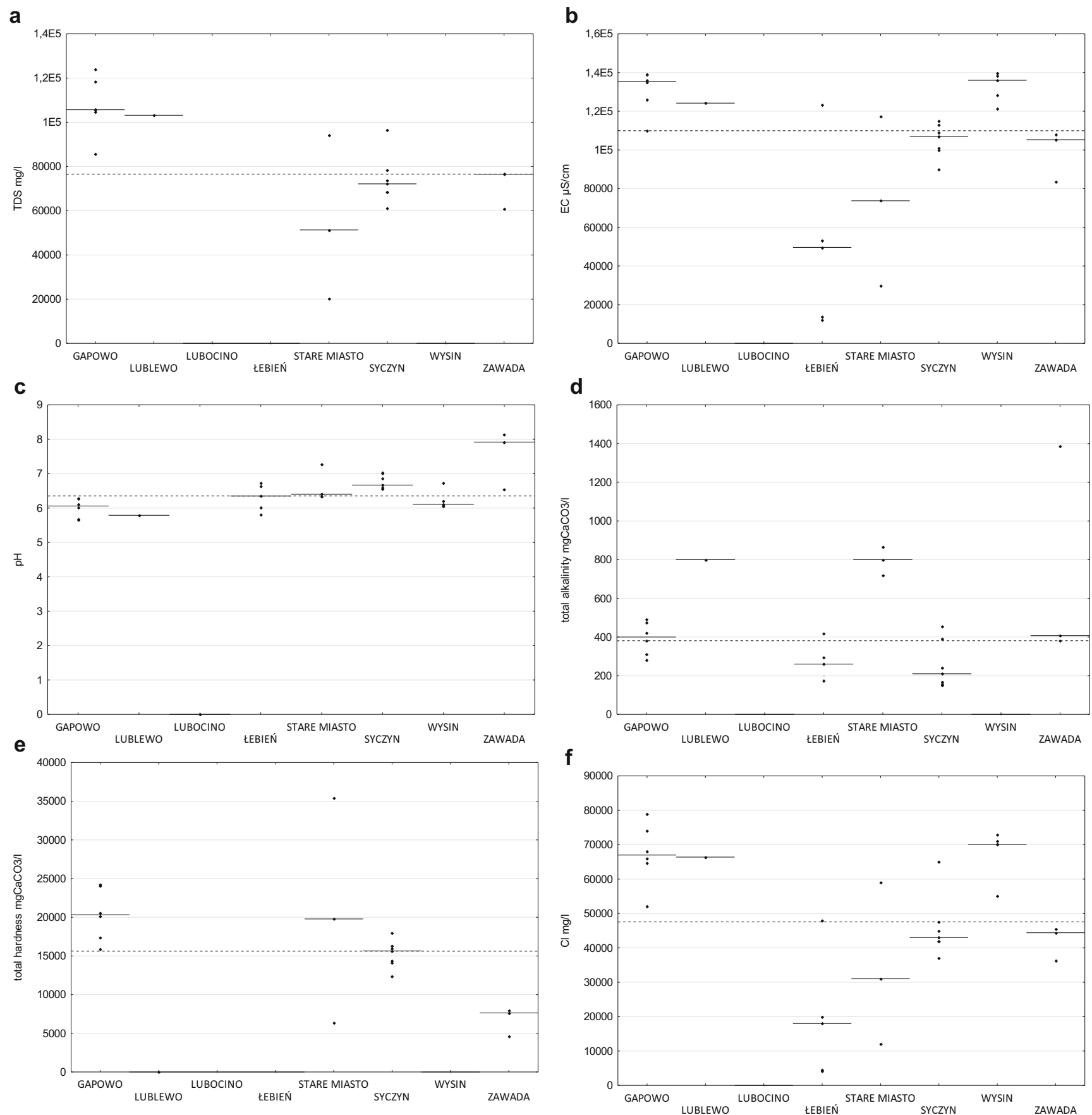

Fig. 2 Comparison of the median values of total dissolved substances concentration (a), electrical conductivity (b), $\mathrm{pH}(\mathbf{c})$, total alkalinity (d), hardness as $\mathrm{CaCO} 3$ (e) and concentrations of chlorides (f), sodium (g), calcium (h), potassium (i), bromides (j), strontium (k), barium (l), lithium

The $\mathrm{pH}$ value was determined within the range from 5.40 to 6.10. TDS ranged from 94,000 to $210,000 \mathrm{mg} / \mathrm{l}$ and alkalinity from 41 to $133 \mathrm{mgHCO}_{3} / 1$. Total suspended solids (TSS) were within the range from 23 to $2600 \mathrm{mg} / \mathrm{l}$ and COD from

(m), and iron (n) for 8 sampling locations (dashed lines) and the general median for the whole set (solid line); raw data are included (diamonds). On the $x$-axis, localization of samples collection

120 to $3240 \mathrm{mg} / \mathrm{l}$. Similar to flowback fluids from other locations, the highest concentration, within the range of $48,000-100,000 \mathrm{mg} / \mathrm{l}$, was reported for chloride. The concentrations of other constituents were as follows: 
g

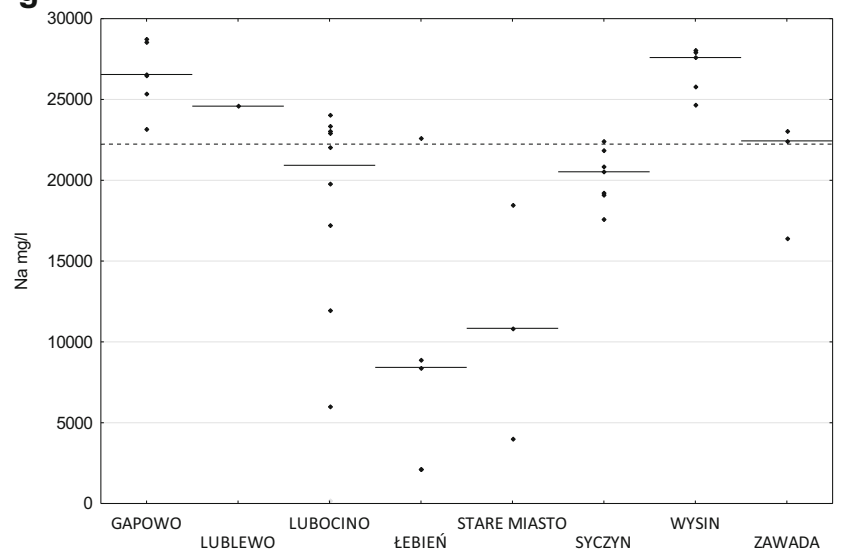

i

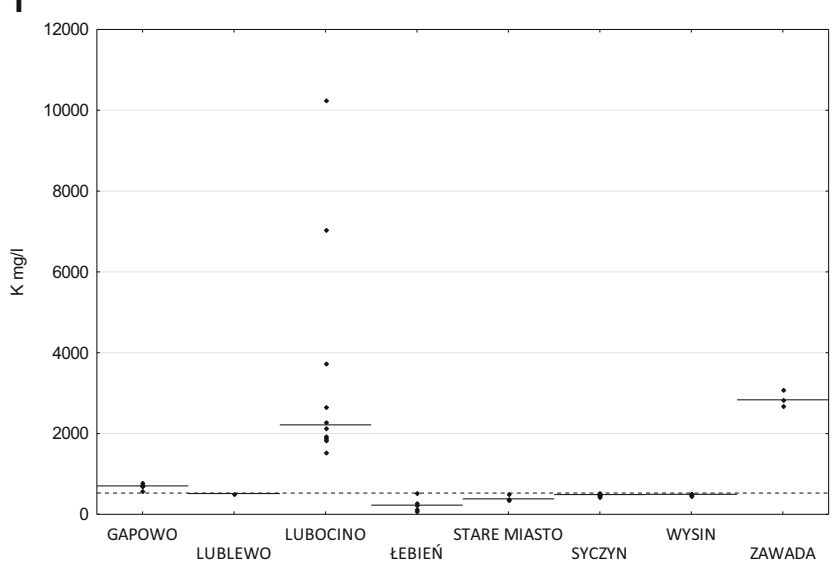

k

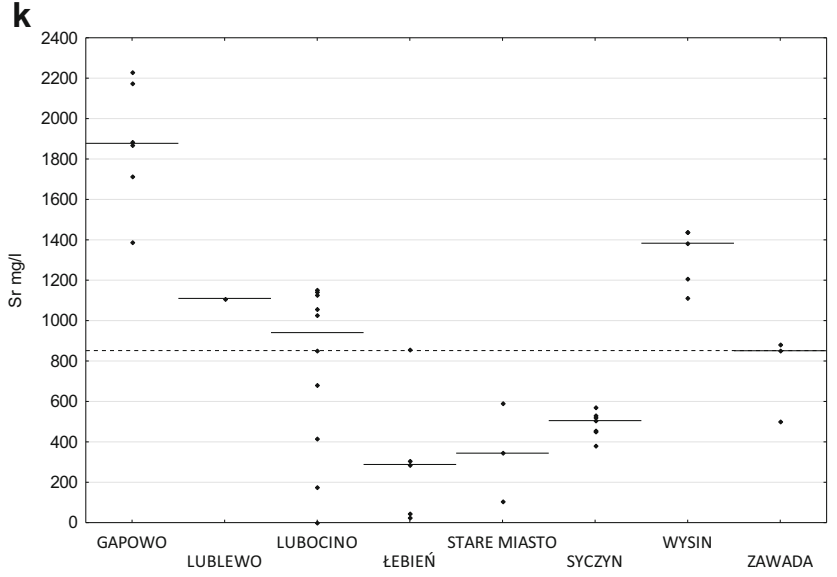

Fig. 2 (continued)

barium from 9.2 to $30 \mathrm{mg} / \mathrm{l}$, iron from 4.2 to $23 \mathrm{mg} / \mathrm{l}$, manganese from 1.60 to $2.80 \mathrm{mg} / \mathrm{l}$, arsenic from 0.48 to $1.40 \mathrm{mg} / \mathrm{l}$, and nickel from 0.16 to $0.88 \mathrm{mg} /$ 1(Busby 2018). Based on the Environment Agency (EA 2011), the concentration of potassium ranged from 28.8 to $40.6 \mathrm{mg} / \mathrm{l}$ and sodium from 9300 to $34,800 \mathrm{mg} / \mathrm{l}$, and electrical conductivity was determined within the range from 133.73 to $176 \mathrm{mS} / \mathrm{cm}$. h

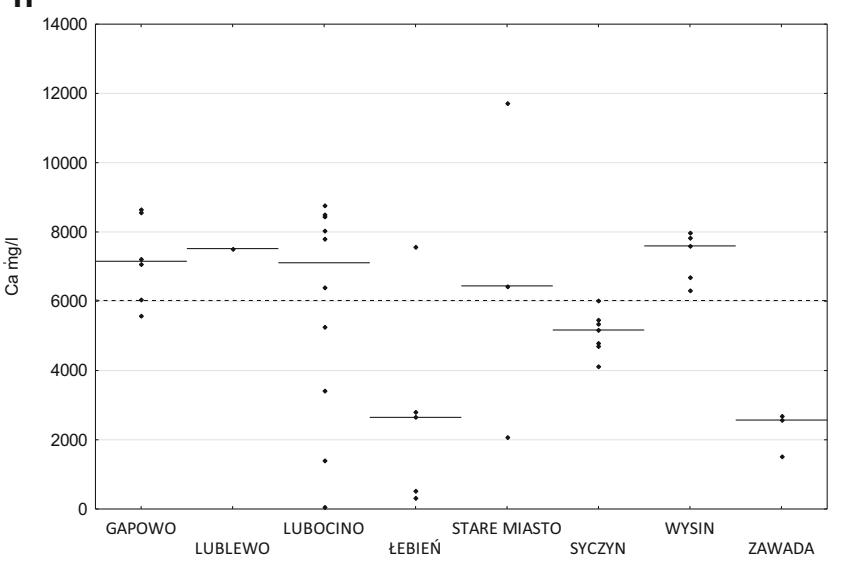

j
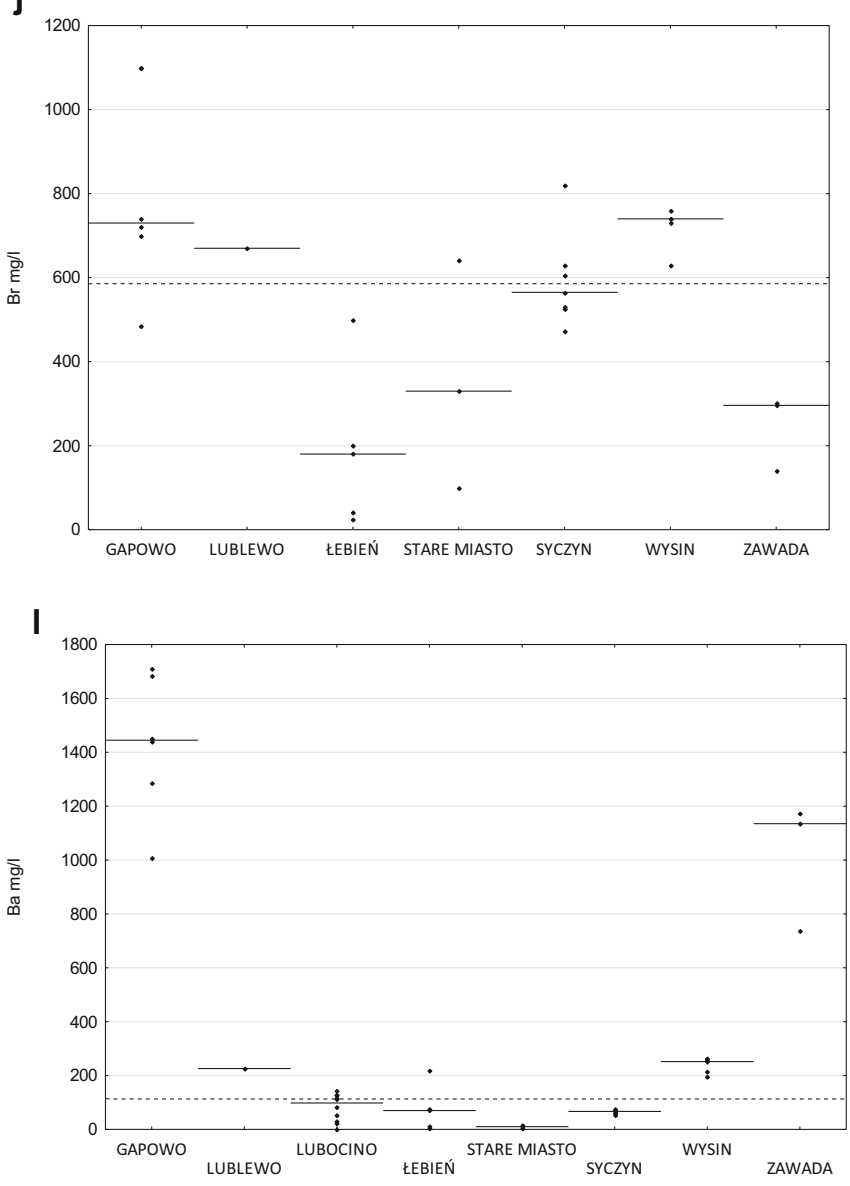

\section{Chemical characteristic of flowback fluids from Poland}

In shale gas formations in Poland, 72 boreholes were drilled, and there were 34 full-scale hydraulic fracturing treatments performed as a part of shale gas exploration activities undertaken by the industry between 2010 and 2016 (Ministry of the Environment 2016). The PGI-NRI conducted several 

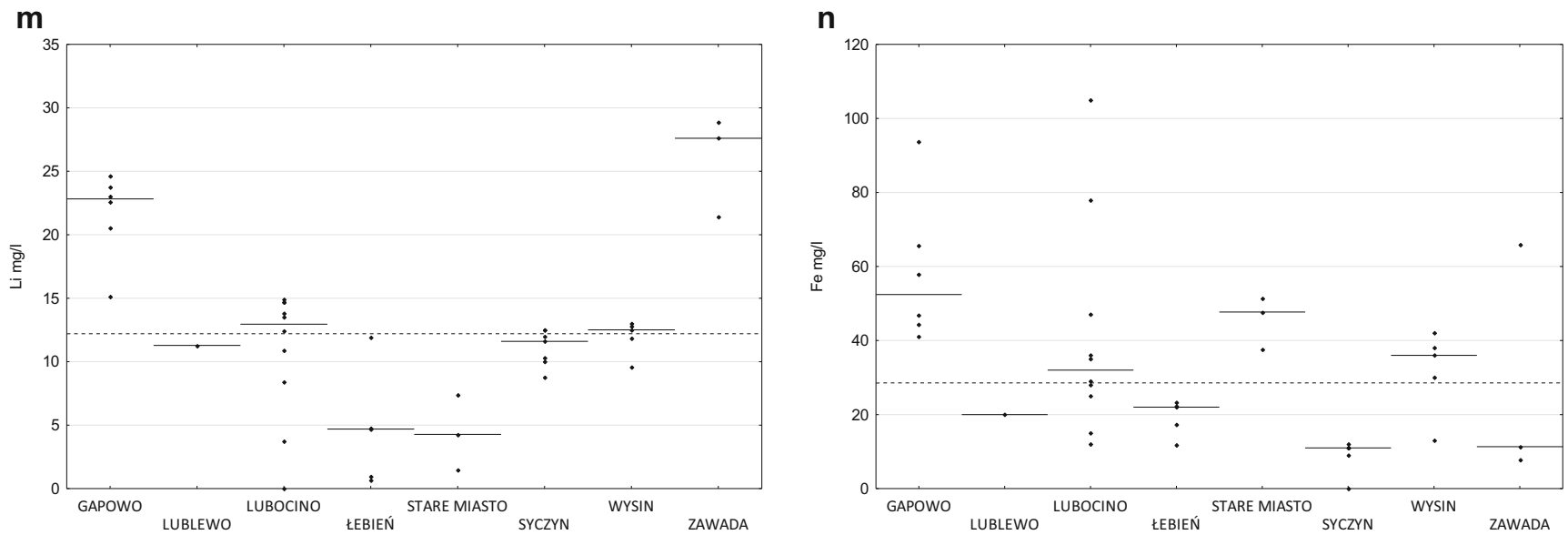

Fig. 2 (continued)

research projects related to the environmental impact of shale gas exploration, where the samples of fracturing fluid and flowback were collected (Konieczyńska et al. 2011; Konieczyńska et al. 2015; Kantor et al. 2015; Fajfer et al. 2016; Konieczyńska et al. 2016 unpublished results). Analytical tests were performed on samples of fracturing fluid and flowback. The samples of fracturing fluid were obtained from one borehole and represent one full-scale hydraulic fracturing treatment. The samples of flowback were collected from 8 boreholes where hydraulic fracturing was conducted (Gapowo, Lublewo, Lubocino, Lebień, Stare Miasto, Syczyn, Wysin, Zawada) in 7 of them in directional sections.

Analyzed flowback samples differed in terms of the time of collecting (counting in days after the hydraulic fracturing treatment) and sampling spot (different outlets of technological line applied on particular well pads to collect the flowback). The geographical location of the drilling and the time duration between hydraulic fracturing and collection of the samples may be the factors of differentiation of the composition of flowback and affect waste management decisions (Balashov et al. 2015; Zambrano et al. 2016; Vieth-Hillebrand et al. 2017). In addition, the differences in the results between samples taken from different spots of the same installation, e.g., upstream or downstream of the gas separator, showed that the initial process of fluid treatment takes place already within the installation, and its efficiency influences the composition of generated fluids to be managed ultimately.

\section{Materials and methods}

In this article, the analysis of the dataset is performed to provide a characteristic of flowback fluids in Poland. For safety reasons, samples of fracturing fluid were provided by a hydraulic fracturing operator. Samples of flowback fluid were collected by trained employees according to the defined scheme for each borehole. The collected samples were tested in order to find out the chemical composition of the fluids and the variability of this composition over time, in order to assess potential threats to the environment and to identify appropriate methods of fluid management including the final disposal procedure.

Flowback sampling campaigns were each time tailored to the technical aspects of the stimulation process applied on the well pad by its industrial operator, in particular the number of hydraulic fracturing stages, the composition of fracturing fluid, and construction of the well-pad infrastructure (technological flowback recovery line). There are several outlets within the technological flowback recovery line possible to be used to collect a sample of flowback, depending on the purpose of the study. The samples collected on choke manifold represent fluid not affected by the surface operation and as the best approximation of downhole fluids may serve in studies focused on fluid-rock reaction in reservoir. Otherwise, the samples collected before and after the removal of volatile constituents indicate the actual efficacy of the separator. The samples collected from collecting tanks represent the average composition of the portion of flowback intended for management (reuse, disposal, etc.). Depending on the purpose of the research, also, the number of samples taken is different for different locations.

In total, forty samples of flowback fluid and two samples of fracturing fluids were analyzed by the Chemical Laboratory of the PGI-NRI between 2010 and 2016, within several research projects. The following parameters were analyzed: $\mathrm{pH}$, electrical conductivity, turbidity, TOC, alkalinity, COD, phenol index, concentration of surface-active agents, cyanide, ammonia, bicarbonate, fluoride, chloride, nitrite, nitrate, phosphate, sulfate, aluminum, silver, arsenic, beryl, cadmium, cobalt, copper, lithium, molybdenum, nickel, lead, rubidium, 
Fig. 3 The share of parameters detected in flowback samples

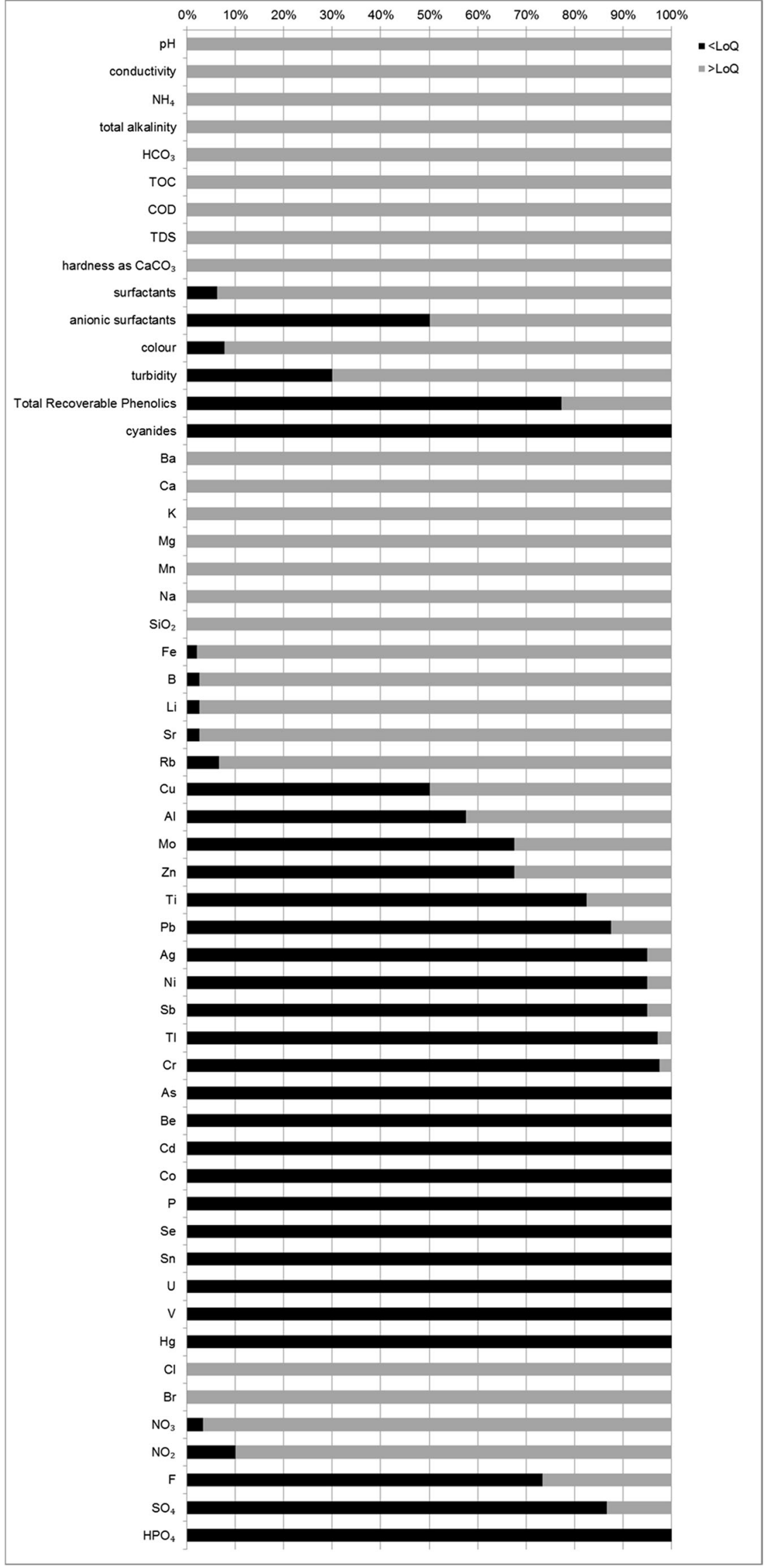


Fig. 4 Comparison of the maximum concentrations of selected parameters in fracturing fluid (gray dots) and in flowback fluid from the same borehole (black dots); the scale is logarithmic $\mathrm{mg} / \mathrm{l}$

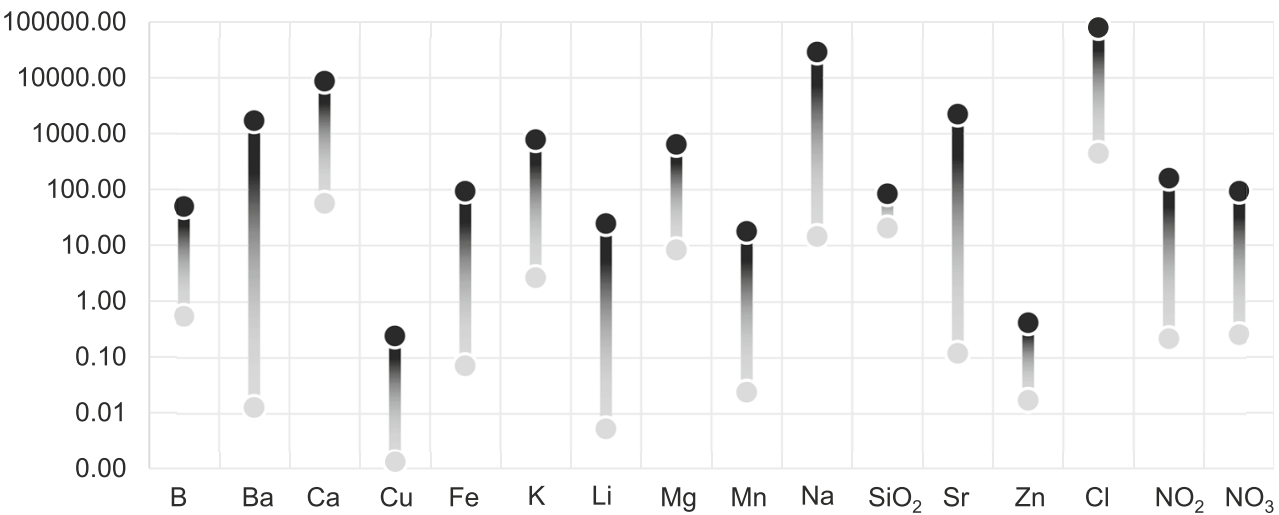

antimony, selenium, tin, tellurium, uranium, vanadium, boron, barium, calcium, chromium, iron, potassium, magnesium, manganese, sodium, silica, strontium, titanium, zinc, and mercury. The samples with high salinity were diluted prior to analysis. Based on elemental analysis, TDS and hardness were computed. All analyses were performed according to Laboratory's methods (description available at www.pgi. gov.pl). All analytical methods were validated in accordance with ISO 17025 method (accreditation certificate number AB 283, issued by Polish Centre for Accreditation). For individual samples, the set of analyzed parameters varied, as the research was carried out to facilitate various projects. The goal of the presented result analyses is to deliver a set of characteristics for flowback fluids generated in Poland.

The analyses include data verification, expert assessment of sample origin, cleaning and standardization of data, and selection and application of most suitable statistical methods. The characterization means a range of values (minimummaximum) and medium value (arithmetical average and median) for analyzed parameters in flowback fluid. The characterization is based on selected samples, assessed as a representative, due to the high variety in dataset. The dataset is a collection of results from different research projects conducted by PGI-NRI in recent years. Parameters obtained for the samples of flowback are presented, including diversity among different locations. Also, not detected substances are revealed. Next, the comparison between fracturing fluid and flowback is given as well as time-related differentiation.

\section{Results}

High content of total dissolved substances was found in the tested samples of flowback (Fig. 2). TDS varied between 20,182 and $123,815 \mathrm{mg} / \mathrm{l}$, arithmetic average $82,270 \mathrm{mg} / \mathrm{l}$, and median 77,424 mg/l (based on 20 samples). As a result of high TDS, the high electrical conductivity of flowback was also measured. The arithmetic average of electrical conductivity measured in thirty samples was $102,577 \mu \mathrm{S} / \mathrm{cm}$ and median $111,500 \mu \mathrm{S} / \mathrm{cm}$. For 2 out of 8 locations, the conductivity levels are low, with a minimum of $12,140 \mu \mathrm{S} / \mathrm{cm}$, while for others, values over $80,000 \mu \mathrm{S} / \mathrm{cm}$ were more characteristic, with the maximum reaching 139,800 $\mu \mathrm{S} / \mathrm{cm}$ (Fig. 2).

Measured $\mathrm{pH}$ values were from 5.66 up to 8.14 with values significantly above 7 recorded for two locations. The median $\mathrm{pH}$ value was 6.38 , and the mean was 6.48 (based on 30 samples).

Alkalinity measured in 25 samples was in the range from 152 to $1385 \mathrm{mgCaCO}_{3} / 1$. Hardness measured in 17 samples ranged from 4577 to $35,418 \mathrm{mgCaCO}_{3} / 1$.

The main constituent of flowback was chloride; its concentration was measured in the range from 4100 to $79,000 \mathrm{mg} / \mathrm{l}$, with an arithmetic average equal to $48,440 \mathrm{mg} / \mathrm{l}$ and median equal to $47,750 \mathrm{mg} / \mathrm{l}$. The average of sodium concentration was $19,232 \mathrm{mg} / \mathrm{l}$ and median was $22,229 \mathrm{mg} / \mathrm{l}$, ranging from 215 to $28,750 \mathrm{mg} / \mathrm{l}$. Also, a significant amount of calcium seemed to be characteristic. On average, it was present in the amount of $5543 \mathrm{mg} / \mathrm{l}$ (median 6036), from 62 to $11,712 \mathrm{mg} / \mathrm{l}$. Potassium ranged from 82 to $10,240 \mathrm{mg} / 1$, on average $1422 \mathrm{mg} / 1$, while the median was $529 \mathrm{mg} / \mathrm{l}$; two samples showed extremely high (compared to the rest of the samples) potassium levels (Fig. 2).

The arithmetic average of bromide concentration was 534 $\mathrm{mg} / \mathrm{l}$, the median was $585 \mathrm{mg} / \mathrm{l}$, and the lowest and highest concentrations were $25 \mathrm{mg} / 1$ and $1100 \mathrm{mg} / 1$, respectively. Strontium was determined in 39 out of 40 tested samples; the highest concentration was $2230 \mathrm{mg} / \mathrm{l}$, and the average was $870 \mathrm{mg} / \mathrm{l}$; similarly, the median was $851 \mathrm{mg} / \mathrm{l}$ (the limit of quantitation (LoQ) is $0.3 \mathrm{mg} / \mathrm{l}$ ).

Fig. 5 Time-related differentiation of flowback: standardized values of $\mathrm{pH}(\mathbf{a})$, electric conductivity EC (b), ammonia (c), total organic carbon (d), boron (e), barium (f), calcium (g), iron (h), potassium (i), lithium (j), magnesium (k), manganese (l), sodium (m), silica (n), strontium (o), chlorides (p), and bromides (r) are given (diamonds) in relation to the day of sampling ( $x$-axis), maximum-minimum range is marked with a line, where appropriate 
a

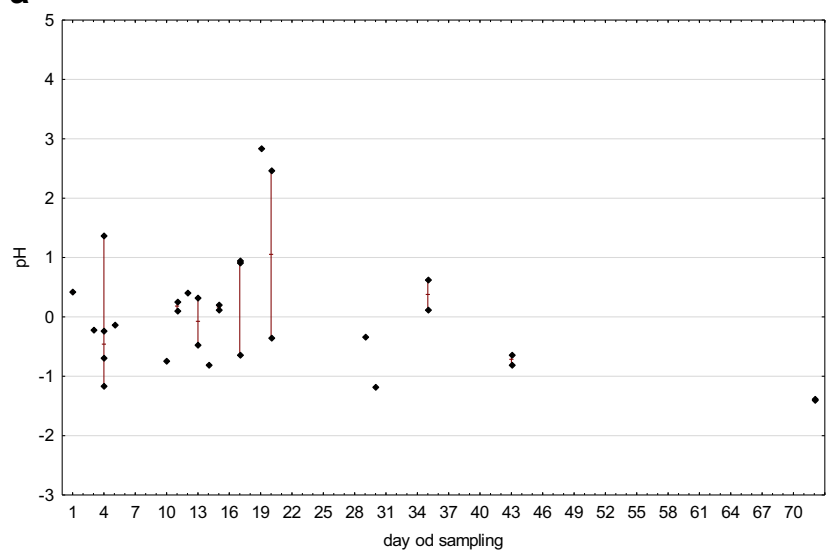

C

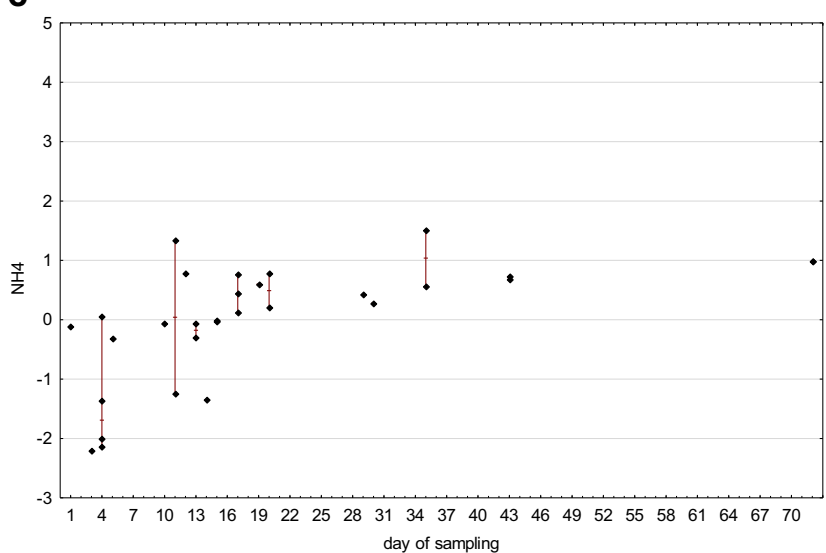

e

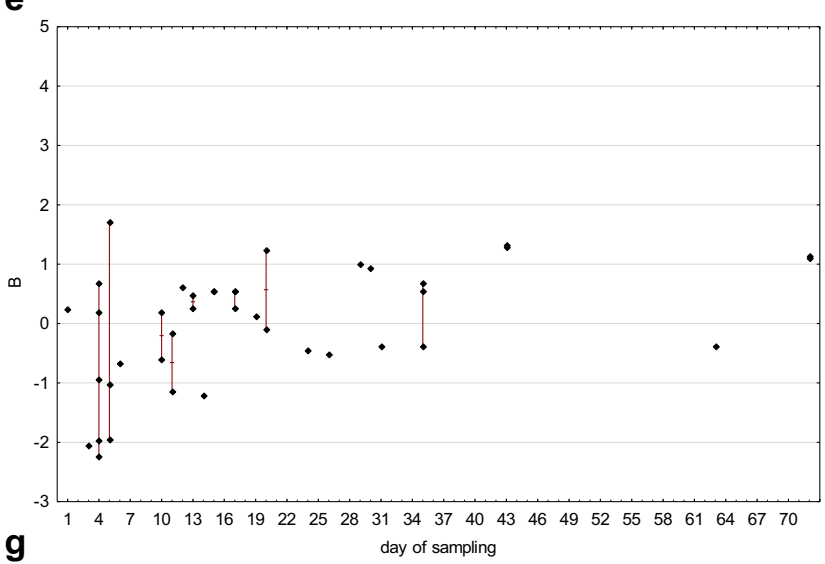

g

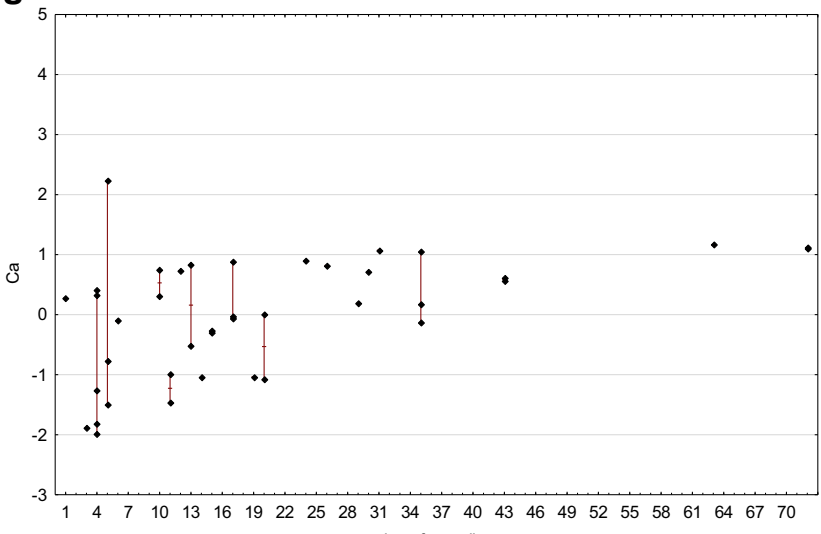

b

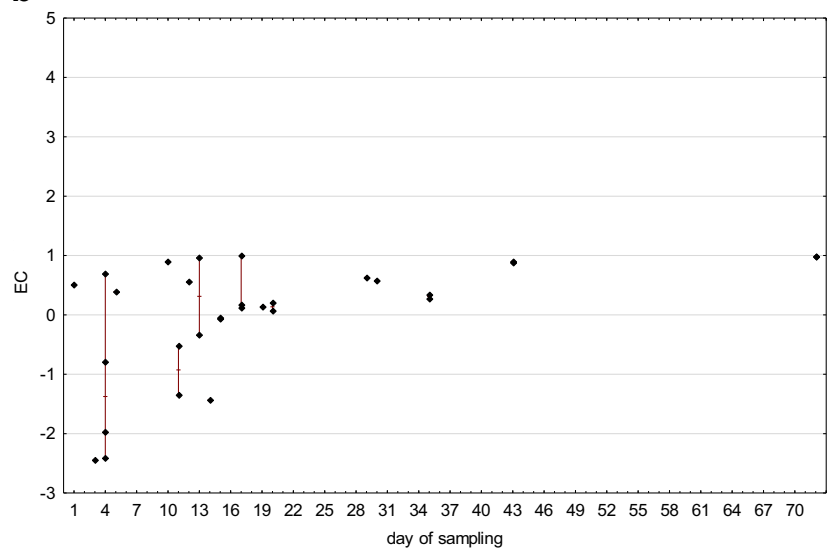

d

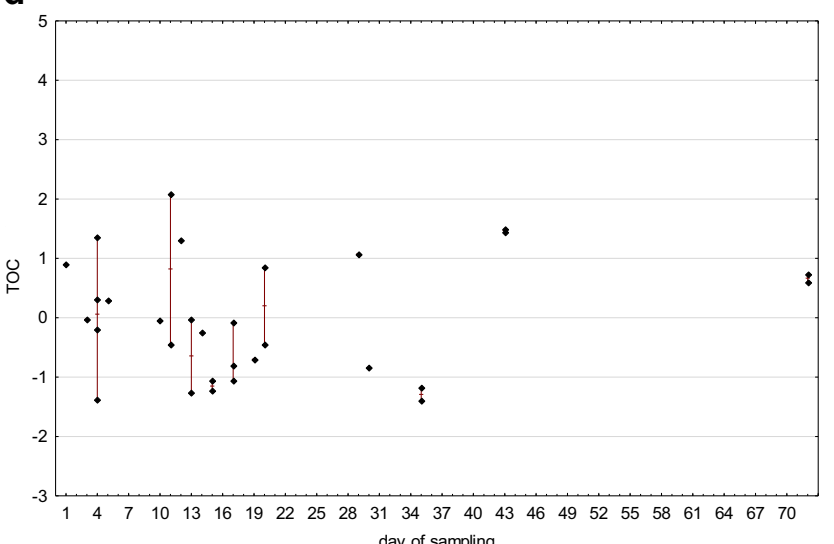

f

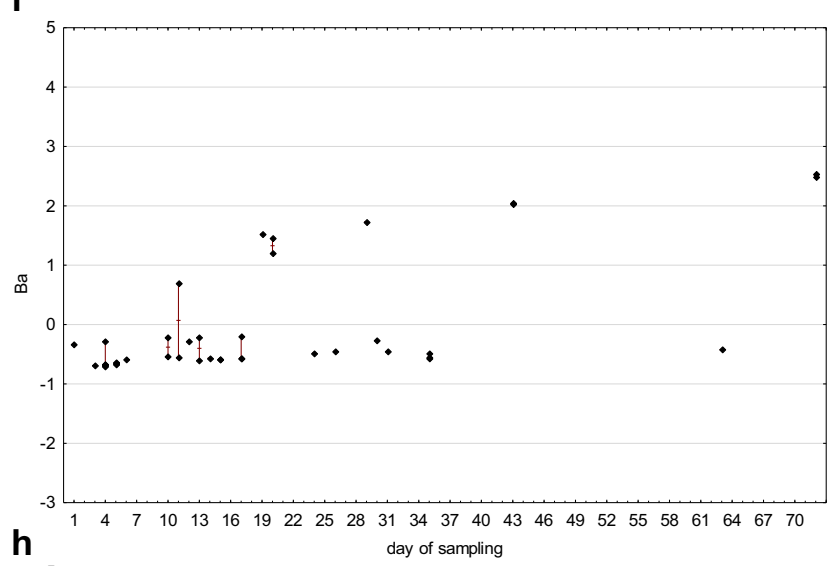

h

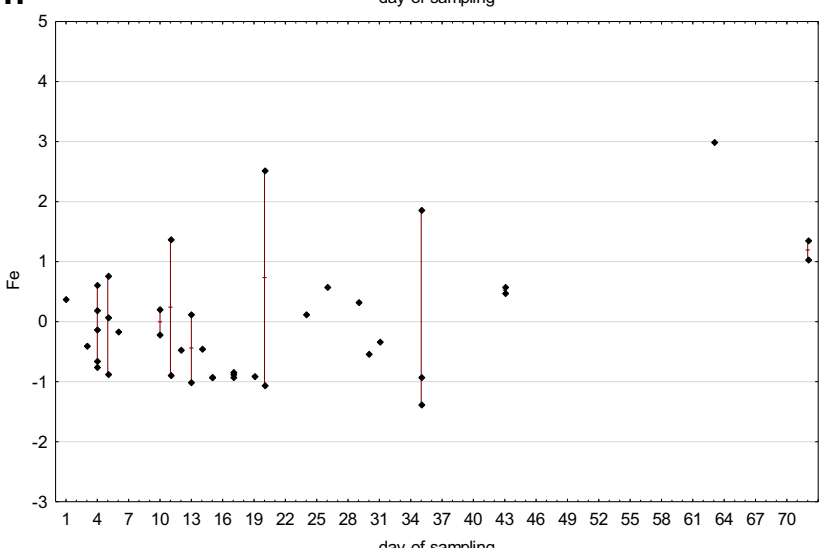

Fig. 5 (continued) 
i

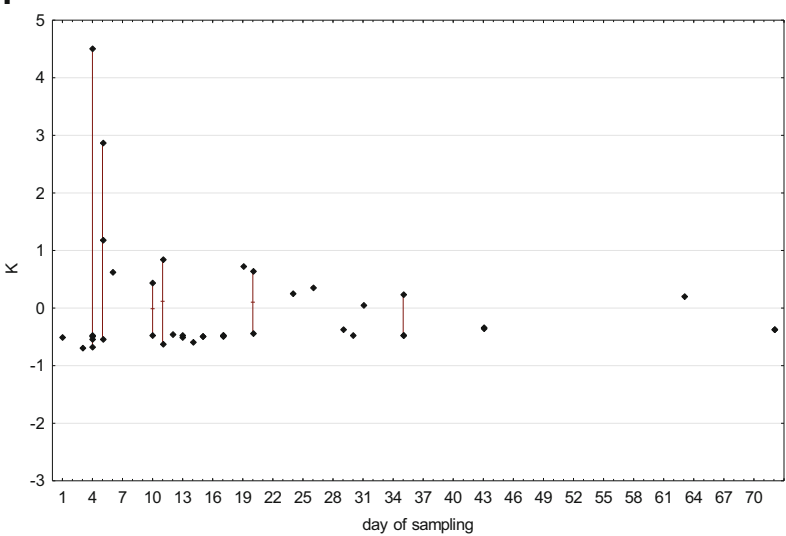

k

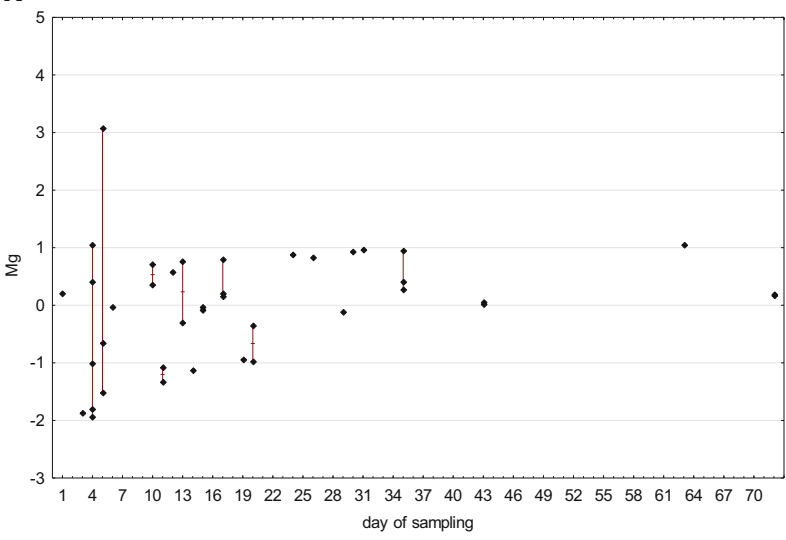

I

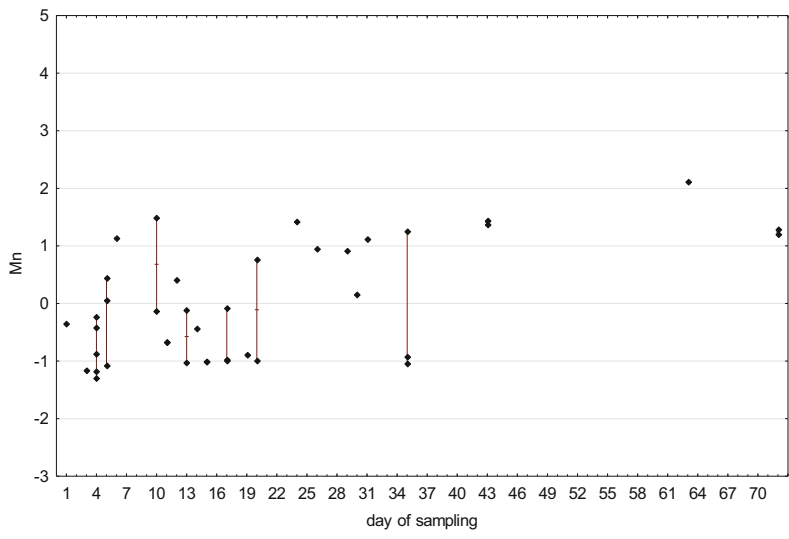

n

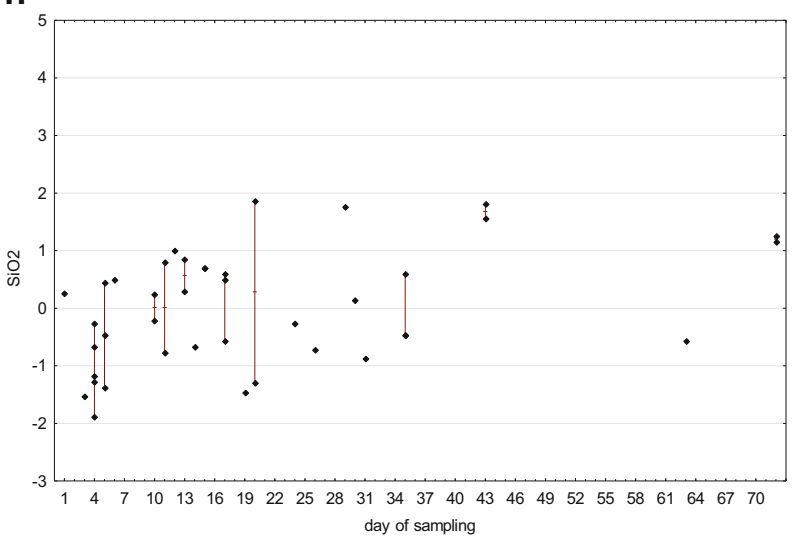

j

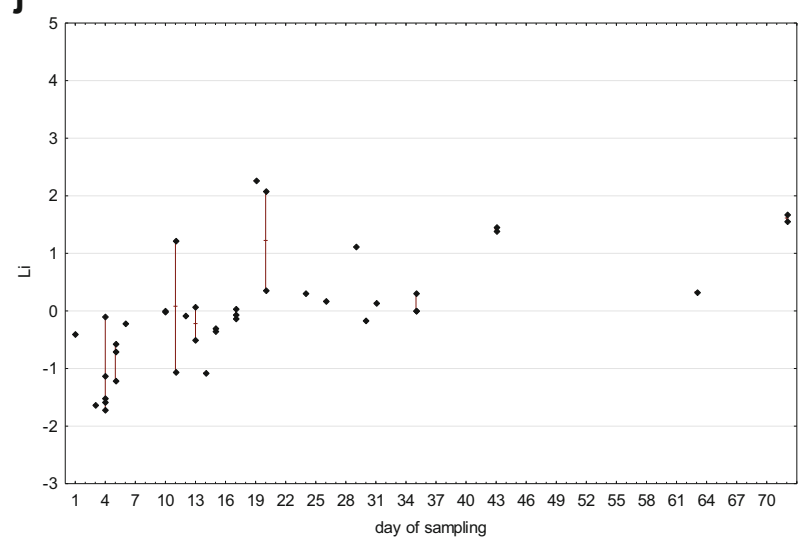

o

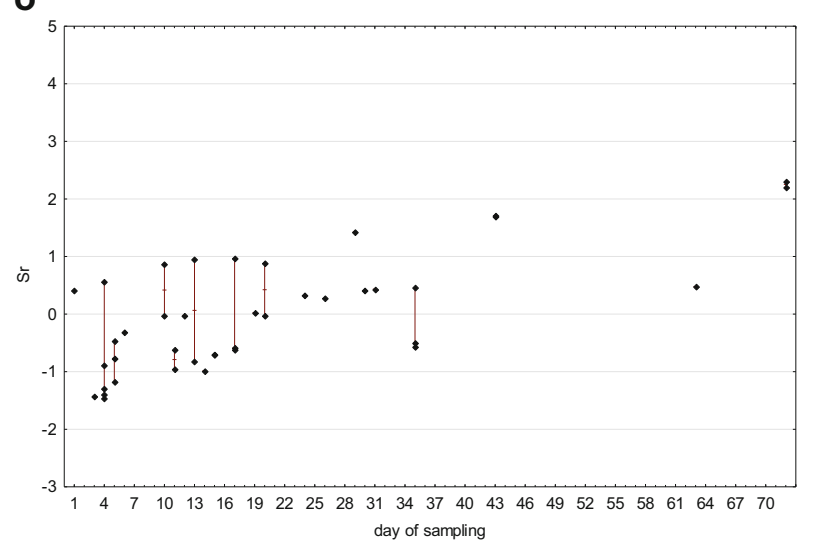

m

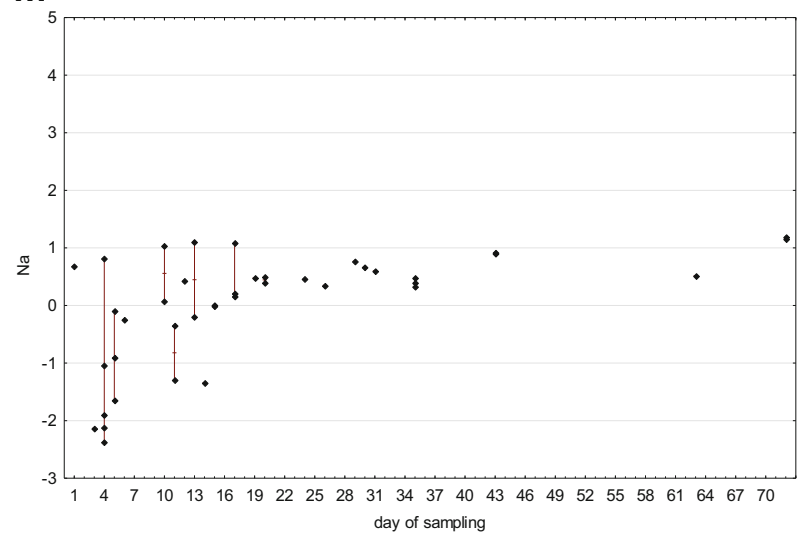

p

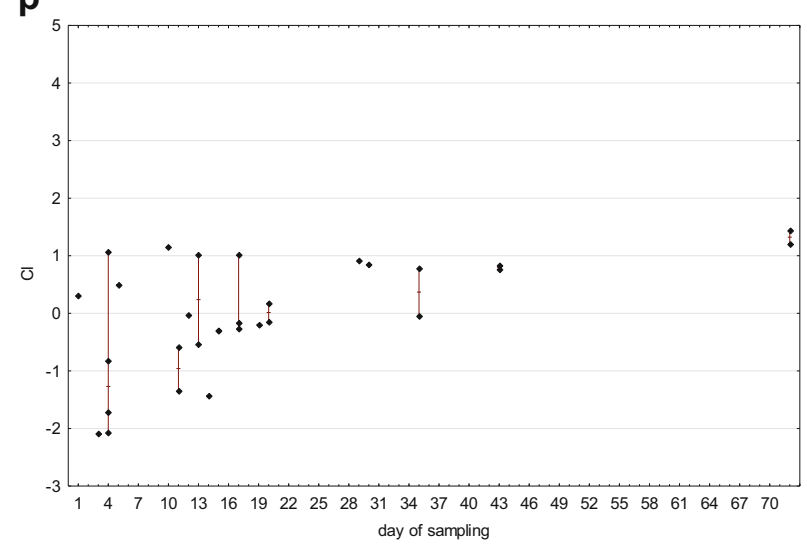

Fig. 5 (continued) 
$\mathbf{r}$

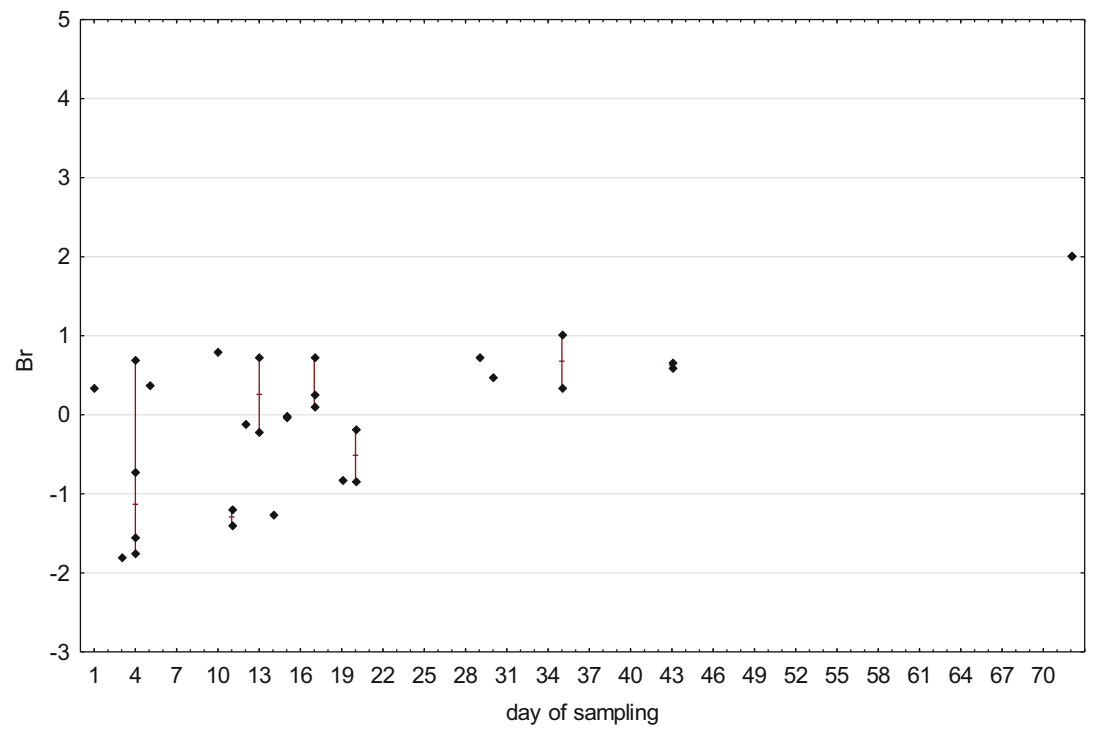

Fig. 5 (continued)

The concentration of barium was in the range from 0.2 to $1710 \mathrm{mg} / \mathrm{l}$; the average concentration was $368 \mathrm{mg} / \mathrm{l}$, while median $115 \mathrm{mg} / \mathrm{l}$ - this significant difference is related to outliers within the dataset.

Lithium was determined in 39 out of 40 tested samples, the highest concentration was $28.9 \mathrm{mg} / \mathrm{l}$, the average was $12.5 \mathrm{mg} /$ 1 , and similarly, the median was $12.2 \mathrm{mg} / \mathrm{l}$ (the limit of quantitation (LoQ) is $0.2 \mathrm{mg} / \mathrm{l}$ ).

Concentrations of iron ranged from 7.69 to $105 \mathrm{mg} / \mathrm{l}$. The mean iron concentration was $33 \mathrm{mg} / \mathrm{l}$, while the median was $28.5 \mathrm{mg} / \mathrm{l}$. In one sample, no iron was found above the quantification limit of $1 \mathrm{mg} / \mathrm{l}$. The non-iron sample represented fluid after pretreatment; in the analogous samples representing the fluid part before the pretreatment line, the level of iron's concentrations was $11-12 \mathrm{mg} / \mathrm{l}$.

Moreover, in the samples of flowback fluids, the presence of silica, boron, magnesium, and manganese as well as sulfate, nitrate, and nitrite was established. Concentrations of other elements were at trace level or below the quantification limit.

There was no evidence of arsenic, beryllium, cadmium, cobalt, phosphorus, selenium, tin, uranium, vanadium, mercury, phosphates, and cyanides in any of the tested samples, whereas components such as lead, silver, nickel, antimony, thallium, chromium, fluorides, sulfates, and phenols were determined only in a few samples, at very low levels of quantification (note that in some cases, the LoQs were higher, due to high salinity of samples with a complicated matrix and need for dilution). For all analyzed parameters, the percentage share of results obtained below the LoQ of a given analytical method is presented on the diagram (Fig. 3).

The comparison of the properties of the fracturing fluid and the flowback fluid clearly shows that the composition of the original fluid has been modified, most likely as a result of contact with the formation and/or reactions occurring in the fluid during and after the hydraulic fracturing treatment. The greatest increases in maximum concentrations were observed for barium, strontium, lithium, sodium, and iron (Fig. 4).

In the case of flowback fluids sampling, it should be clarified that each subsequent sample represents a portion of the fluid that may have undergone other processes than the previous one. The later the sample is collected, the more likely the original chemical composition will be transformed due to reactions taking place in the fluid itself and between the fluid and the reservoir. The longer the period, the greater opportunities to achieve equilibrium under high temperature and pressure conditions. The variability of individual parameters depending on the sampling date, taking into account standardized raw data, is presented in the charts (Fig. 5).

\section{Statistical analysis of fluid differentiation}

The collected samples of flowback fluids, as mentioned earlier, differed in terms of the time of sampling and the place of collection. One of the methods of assessing the diversity of the analyzed variables is statistical tests, which can be used to assess whether the relationships between the variables observed in the analyzed dataset are statistically significant, which allows drawing conclusions in the general context (population). The selection of the appropriate test depends on several factors; the most important of which are the nature of the variable, sample size, and distribution.

Here, nonparametric methods were used due to the fact that the independent variables are ordinal. Correlation coefficients were used to present the relationship between the selected physicochemical parameters and sampling time. To show differences between the groups (defined according to the 
sampling spot), tests between independent groups were applied. Statistical tests were performed on standardized raw data after removing missing data.

The correlation between physicochemical parameters and sampling time was investigated with Spearman's rank correlation coefficient $R$ (Gauthier 2001), which is applicable for ordinal and quantitative variables. The $p$ value threshold for statistical significance was $p=0.05$. Spearman's correlation coefficient ranges from -1 to 1 , with a positive value representing a positive correlation - an increase or decrease in the value of both analyzed variables. When the values of one variable tend to decrease with an increase of the other one, then the correlation coefficient is negative. It is assumed that correlation is very weak when the absolute value of the coefficient is in the range from 0 to 0.3 , fairly strong in the range from 0.3 to 0.5 , and very strong when the coefficient value is close to 1 . The correlation between sampling time and the following physicochemical parameters were investigated: $\mathrm{pH}$, electrical conductivity, TOC, concentrations of ammonia $\left(\mathrm{NH}_{4}\right)$, boron, barium, calcium, iron, potassium, lithium, magnesium, manganese, sodium, silica, strontium, chloride, and bromide. The calculated Spearman's rank correlation coefficients are presented in Table 1.

There is a statistically significant positive correlation between sampling time and the following parameters: electrical conductivity, concentration of ammonia, strontium, sodium, barium, chloride, bromide, calcium, boron, manganese, lithium, silica, and magnesium. The results suggest that concentrations of those chemicals increase with an increase of duration time of contact between fracturing fluid and reservoir rock. They were likely leached from the rock during hydraulic fracturing in high pressure and temperature conditions.

The concentration of potassium and iron and $\mathrm{pH}$ value and TOC are independent of sampling time; there is no statistically significant correlation between sampling time and those parameters.

Further, statistical analysis was devoted to changes of physicochemical parameters of flowback fluids between a well head and a wastewater storage tank. At the surface, the flowback fluid is equilibrated to ambient conditions. The pressure is reduced; after cooling down, the solid suspension is removed from flowback fluids, and gaseous and organic phases are removed in 2 or 3 phases separator. Finally, the flowback fluid is collected in a tank with free access to atmospheric air (regardless if tanks are closed or open, there is always air above the fluid surface). As a result, the physicochemical parameters of the flowback fluid change during the collection process.

The sampling time and spot are known for each sample of the flowback fluid in the analyzed dataset. Based on this, 4 groups were distinguished, from the unrepresentative to the most representative fluid samples. This classification was made on the basis of expert knowledge, the experience, and observations of people collecting samples.

Hence, the samples can be divided in four groups: (A) samples from initiation of recovery process, which composition is different than fluid received latter; mainly the solution used for drilling the plugs; samples may be unrepresentative in

Table 1 Results of R-Spearman correlation: day of sampling versus parameters values

\begin{tabular}{|c|c|c|c|}
\hline Parameter & $\begin{array}{c}\text { Spearman's rank } \\
\text { correlation coefficient } \\
\mathbf{R}\end{array}$ & $\begin{array}{c}\text { Correlation } \\
\text { (according to R) }\end{array}$ & p-value \\
\hline $\mathrm{pH}$ & -0.202766 & weak negative & 0.282546 \\
\hline electrical conductivity & 0.508421 & medium positive & 0.004122 \\
\hline $\mathrm{NH}_{4}$ & 0.738346 & strong positive & 0.000003 \\
\hline $\mathrm{TOC}$ & -0.033906 & weak negative & 0.858825 \\
\hline $\mathrm{B}$ & 0.511810 & strong positive & 0.000736 \\
\hline $\mathrm{Ba}$ & 0.631362 & strong positive & 0.000013 \\
\hline $\mathrm{Ca}$ & 0.514920 & strong positive & 0.000675 \\
\hline $\mathrm{Fe}$ & 0.133111 & weak positive & 0.412886 \\
\hline $\mathrm{K}$ & 0.297773 & weak positive & 0.062021 \\
\hline $\mathrm{Li}$ & 0.774756 & strong positive & 0.000000 \\
\hline $\mathrm{Mg}$ & 0.353307 & medium positive & 0.025331 \\
\hline $\mathrm{Mn}$ & 0.478640 & medium positive & 0.001783 \\
\hline $\mathrm{Na}$ & 0.616231 & strong positive & 0.000023 \\
\hline $\mathrm{SiO}$ & 0.396785 & medium positive & 0.011247 \\
\hline $\mathrm{Sr}$ & 0.627791 & strong positive & 0.000014 \\
\hline $\mathrm{Cl}$ & 0.497269 & strong positive & 0.005178 \\
\hline $\mathrm{Br}$ & 0.523821 & strong positive & 0.002970 \\
\hline
\end{tabular}

In gray indicated $p$ value less than 0.05 , which means statistically significant 
terms of the characteristics of the bulk flowback fluid for its further management; usually, small amounts of this kind of waste could be generated on the well pad; (B) samples taken before the first stage of treatment, without preliminary separation of gas and suspended solids; in normal operation such waste could be received only as a result of line failure or loss of separator efficiency; (C) samples of flowback fluid after the initial (on-site) treatment, taken from the reservoir tank;
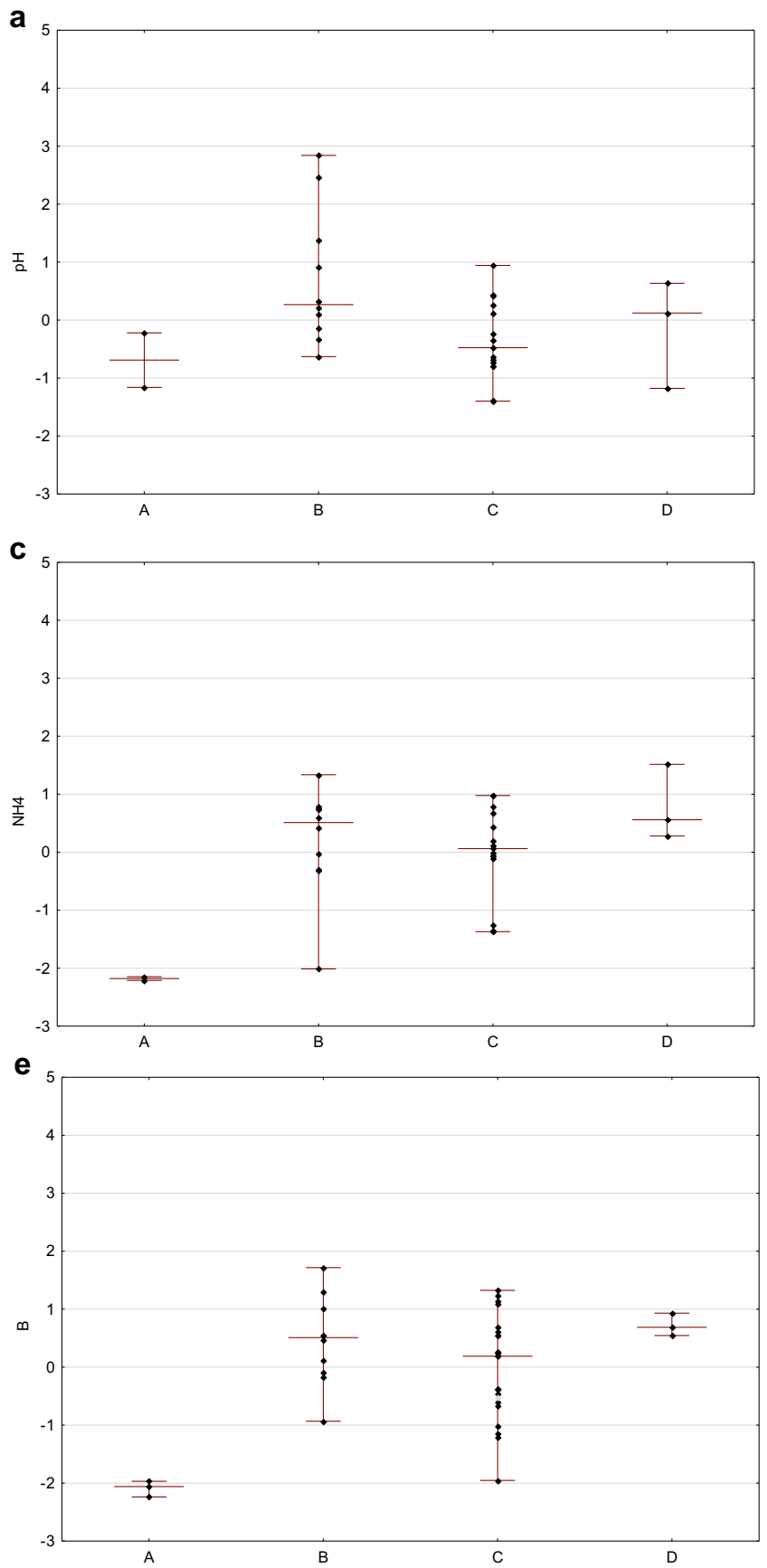

Fig. 6 Group-related differentiation of flowback: standardized values of $\mathrm{pH}$ (a), electric conductivity (b), ammonia (c), total organic carbon (d), boron (e), barium (f), calcium (g), iron (h), potassium (i), lithium (j), magnesium (k), manganese (l), sodium (m), silica (n), strontium (o), mixture of different batches of the pretreated fluid from fracturing process collected over several hours; (D) samples taken from a collective tank, different batches of the pretreated flowback fluid collected for a long time; the most representative for the bulk flowback - a mixture of pretreated flowback fluids from all stages of fracturing process.
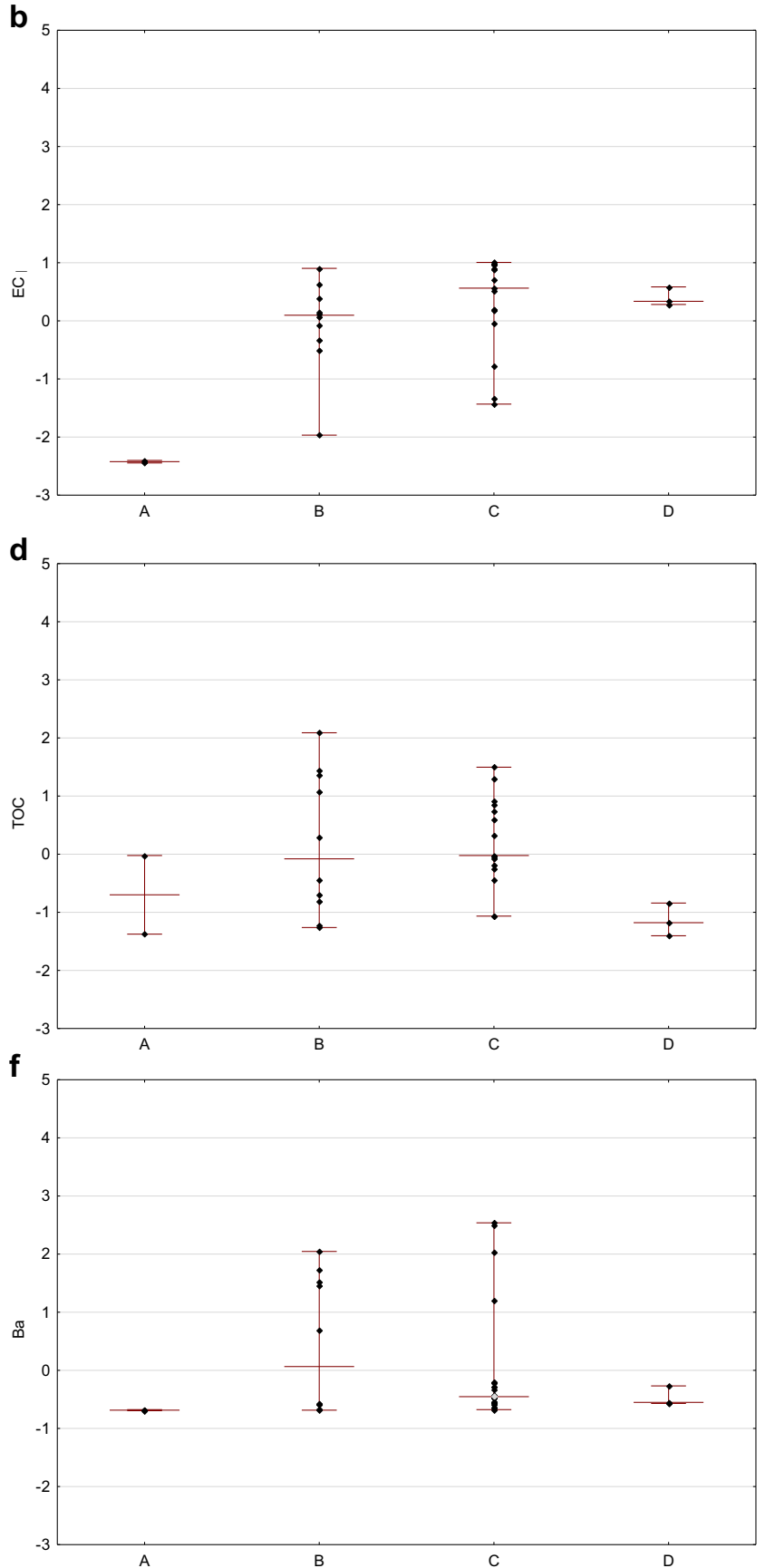

chlorides (p), and bromides (r) are given (diamonds) in relation to the level of representativeness ( $x$-axis) (groups are defined in the text), within the groups maximum and minimum is marked with short line and median is marked with long line 
g

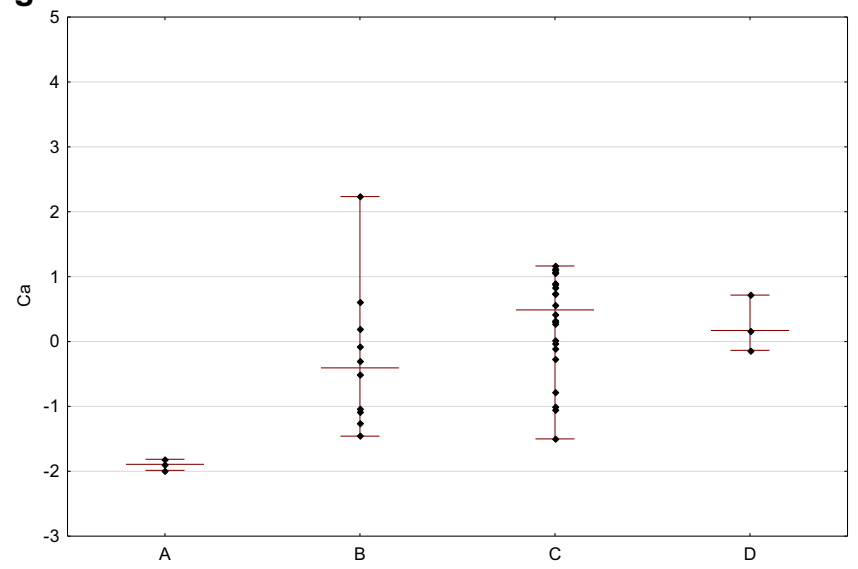

i

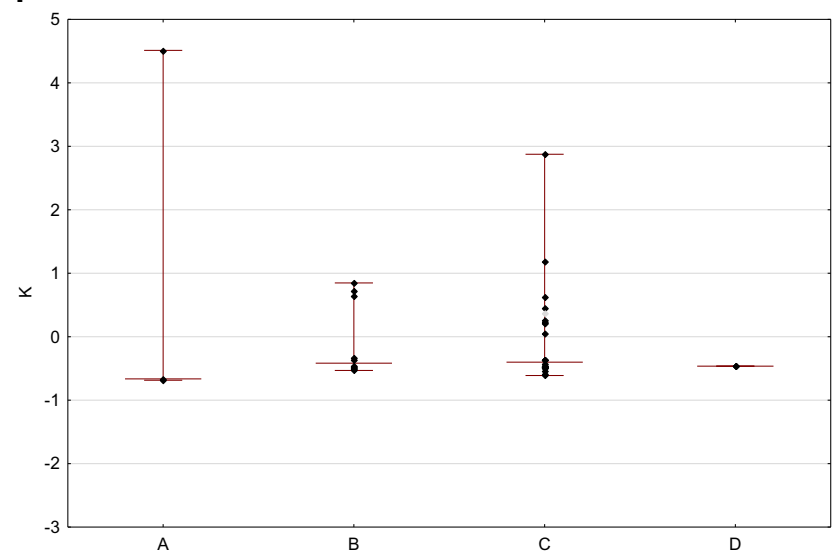

k

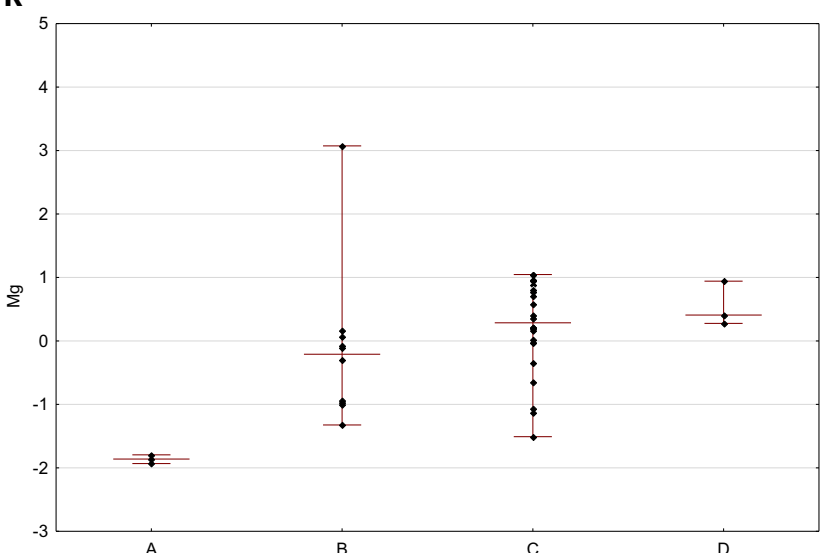

Fig. 6 (continued)

The differentiation between the groups is presented by the concentration ranges and the medians in each group in Fig. 6 (standardized data used).

The correlation between groups was investigated with the nonparametric Kruskal-Wallis test (Kruskal 1952). The grouping variable was ordinal, from the least (group A) to the most representative (group D). Quantitative variables were standardized. The null hypothesis of no difference between the groups was tested. The $p$ value threshold for statistical h

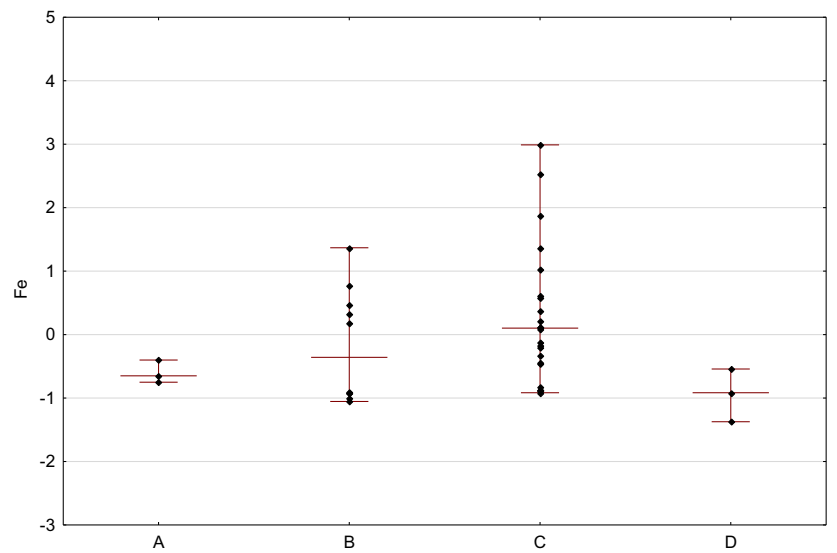

j

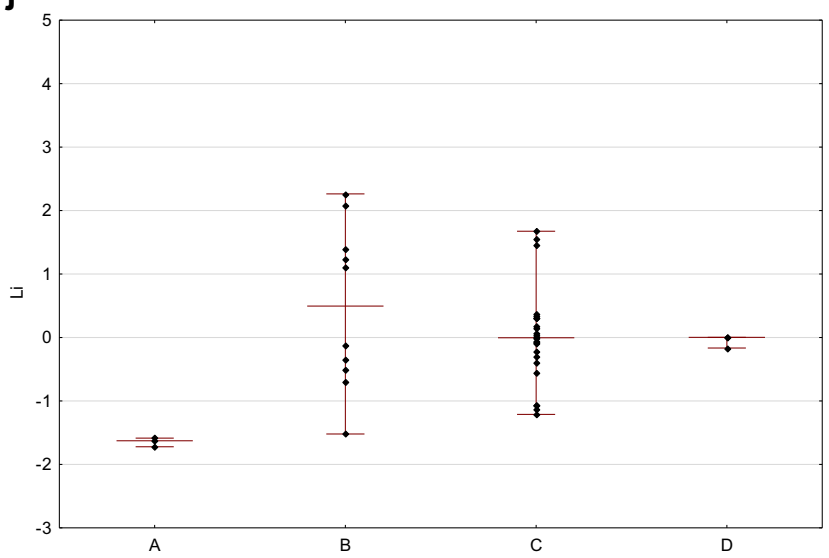

I

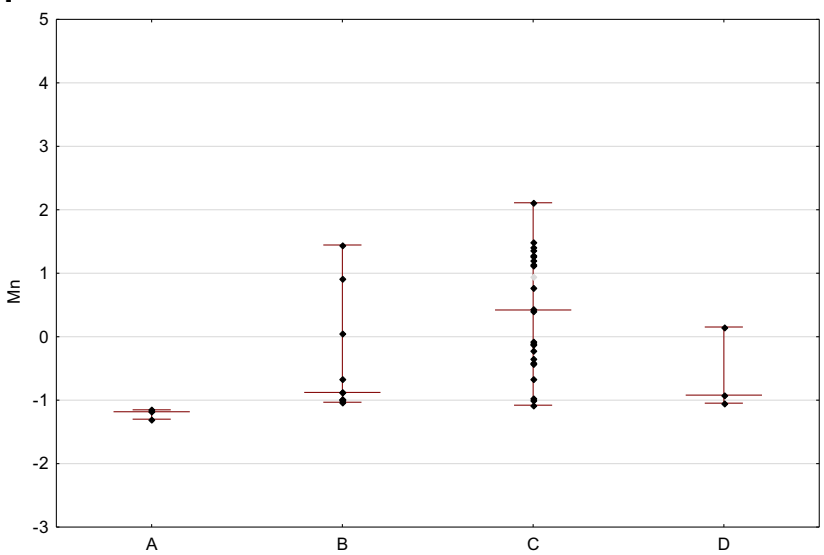

significance was $p=0.05$. The results of the test are presented in Table 2.

A statistically significant result of the Kruskal-Wallis test, meaning that at least one group differs from the other one, was obtained for the following parameters: electrical conductivity, concentration of boron, calcium, lithium, magnesium, manganese, sodium, strontium, chloride, and bromide.

Post hoc tests were used in order to indicate the group which differed the most from other groups (Siegel and 


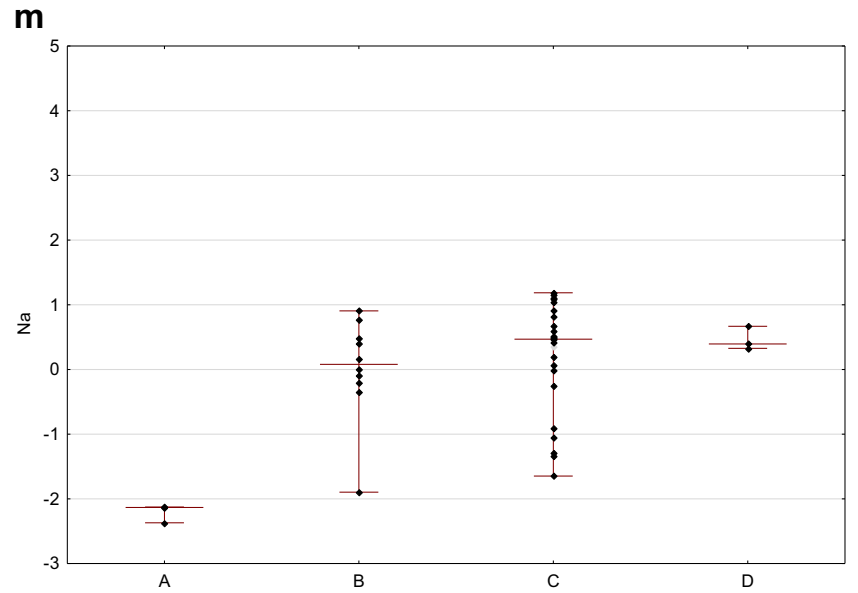

n

0

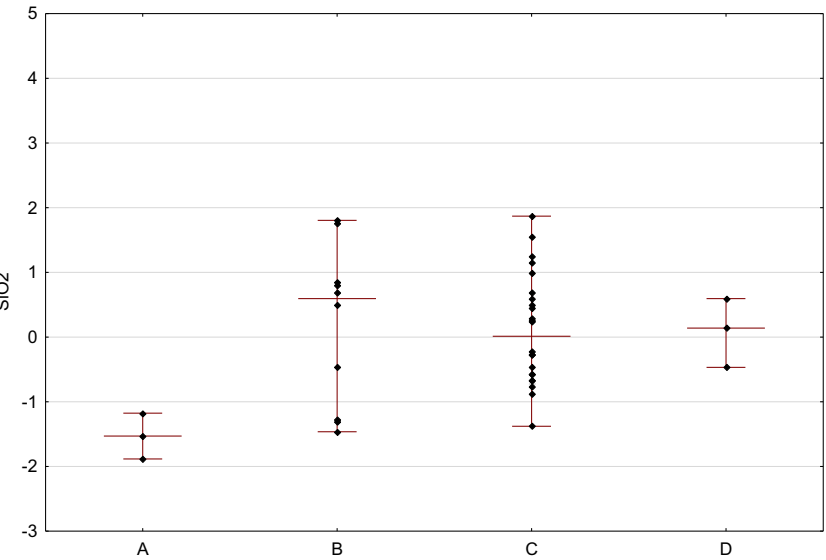

p
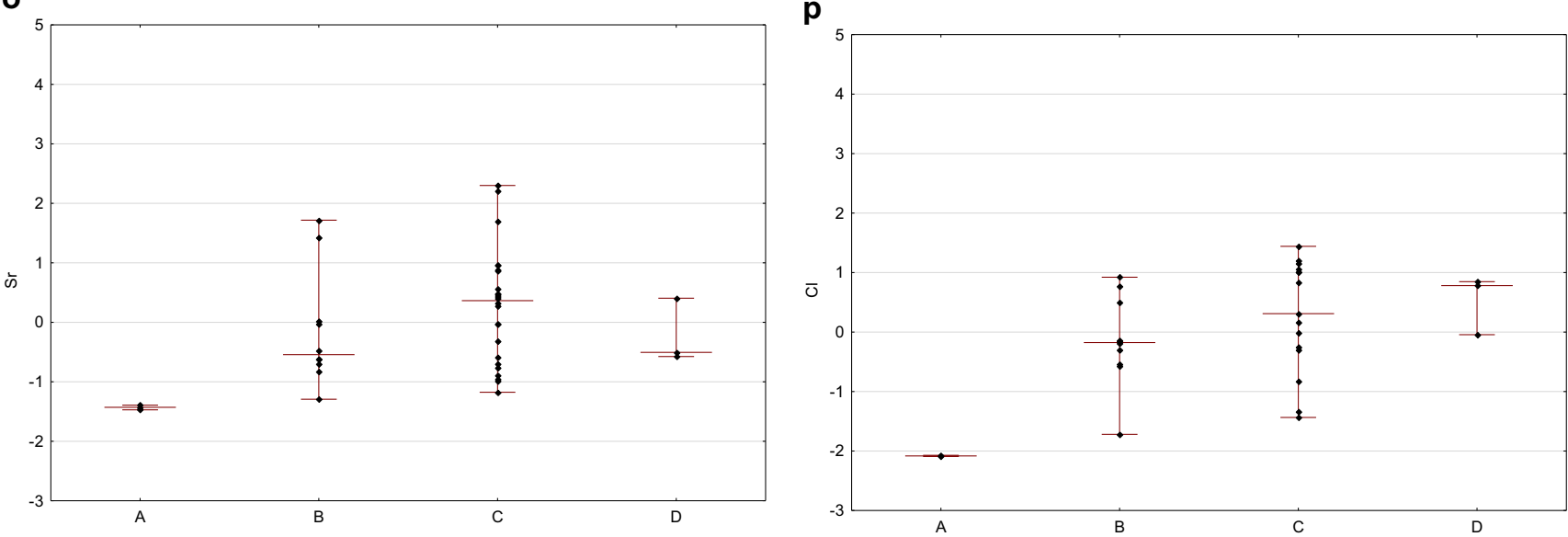

r

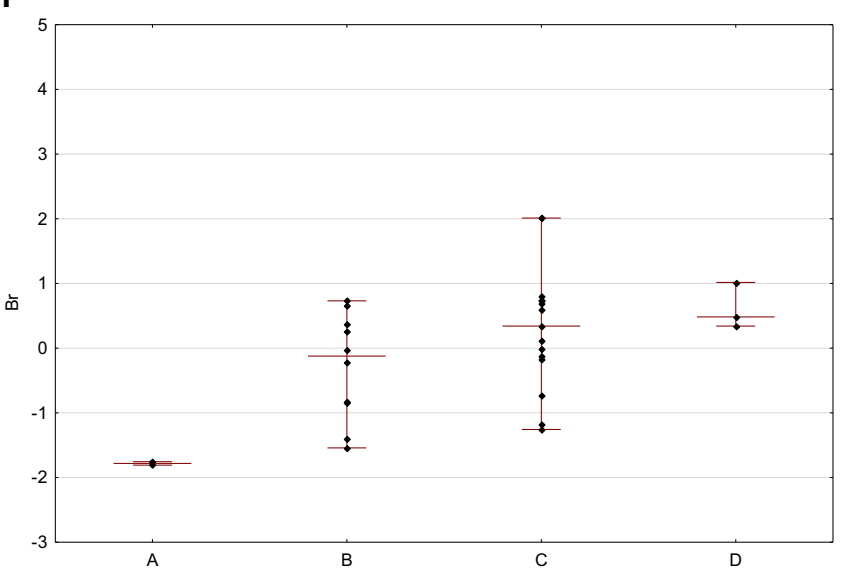

Fig. 6 (continued)

Castellan Jr. 1988). For this purpose, multiple comparisons of mean ranks for all statistics were used. It was found that the flowback samples in group A differed from groups B and D by concentration of boron; from group $\mathrm{C}$ by concentration of barium, manganese, sodium, and strontium; and from groups $\mathrm{C}$ and $\mathrm{D}$ by magnesium. The samples from group $\mathrm{A}$ may be used in the study on the interaction between fracturing fluid and reservoir rock; however, they cannot be used in the study on the development of the treatment process of flowback fluid. The composition of samples from group A varied the most from other groups and did not represent the average composition of waste produced after the fracturing process. The differences in the composition of samples from groups B, C, and D were not significant. 
The applied statistical tests confirmed a significant relationship between the properties of flowback fluid (expressed by the value of a given parameter) and the time of sampling and sampling spot. The following parameters differentiated the most: electrical conductivity, concentration of $\mathrm{NH}_{4}$, boron, barium, calcium, lithium, magnesium, manganese, sodium, silicon, strontium, chlorides, and bromides. Otherwise, for $\mathrm{pH}$, TOC, concentration of potassium, and iron, there were no changes observed due to sampling time or sampling spot.

\section{Determining the ranges of parameters characteristic for Polish flowback fluids}

Knowing the chemical constituents of flowback is crucial for informative decisions on its appropriate management. Based on this information, it can be concluded whether the collected fluid can be recovered or neutralized (including neutralization by disposal). In addition, this information should be also used to prepare a mining waste management program, which, in accordance with legal regulations, is obligatory to enable the waste to be deposited in the mining waste treatment facility. The data on the chemical composition of flowback fluids available in the literature most often provided the ranges of selected parameters. Such generalized information is sufficient for preliminary works, as long as the user makes an independent assessment of the credibility and reliability of the processed data. Even assuming that the results met all the standards for analytical uncertainty, the reliability of descriptive statistics may also be affected by selection and number of samples, place and method of sampling, and sampling time, whether the samples came from one or several boreholes or/and treatments or are they characteristic for specific geographic location.

Within the analyzed dataset, 3 out of 40 samples were considered unrepresentative, based on the detailed expertise on the technological process of fracturing and the circumstances of the samples collection (time and place of sampling), as well as on the basis of statistical testing results (samples from group A differed from others).

In Table 3, the ranges, arithmetic averages, and medians are provided for selected parameters: TDS, concentration of chloride, sodium, calcium, potassium, barium, bromide, iron, strontium, and lithium. The presented characteristics were first calculated for the full dataset (40 samples), then taking into account only representative samples (37 samples).

Table 3, column 4, shows the differences in indicators between the presented datasets. Discarding unrepresentative samples eliminates the extreme potassium concentration found in one of the samples. The mean and median values for the representative set to change by

Table 2 Results of ANOVA of Kruskal-Wallis rank and post hoc multiple comparisons (two sided); representativeness as a grouping variable

\begin{tabular}{|c|c|c|c|c|c|c|c|}
\hline Parameter & $\begin{array}{c}\text { ANOVA of Kruskal- } \\
\text { Wallis rank }\end{array}$ & \multicolumn{4}{|c|}{ Multiple comparisons (two-sided) } \\
\hline & & AB & AC & AD & BC & BD & CD \\
\hline pH & 0.0883 & 0.5418 & 1.0000 & 1.0000 & 0.1123 & 1.0000 & 1.0000 \\
\hline $\begin{array}{c}\text { electrical } \\
\text { conductivity }\end{array}$ & 0.0438 & 0.5761 & 0.0584 & 0.2403 & 0.6455 & 1.0000 & 1.0000 \\
\hline $\mathrm{NH}_{4}$ & 0.0648 & 0.1355 & 0.2529 & 0.0572 & 1.0000 & 1.0000 & 1.0000 \\
\hline $\mathrm{TOC}$ & 0.0905 & 1.0000 & 1.0000 & 1.0000 & 1.0000 & 0.2319 & 0.1173 \\
\hline $\mathrm{B}$ & 0.0111 & 0.0191 & 0.0770 & 0.0170 & 1.0000 & 1.0000 & 0.8128 \\
\hline $\mathrm{Ba}$ & 0.0530 & 0.0775 & 0.0367 & 0.4495 & 1.0000 & 1.0000 & 1.0000 \\
\hline $\mathrm{Ca}$ & 0.0062 & 0.4502 & 0.0089 & 0.2792 & 0.2383 & 1.0000 & 1.0000 \\
\hline $\mathrm{Fe}$ & 0.0661 & 1.0000 & 1.0000 & 1.0000 & 0.9904 & 0.9904 & 0.1140 \\
\hline $\mathrm{K}$ & 0.7883 & 1.0000 & 1.0000 & 1.0000 & 1.0000 & 1.0000 & 1.0000 \\
\hline $\mathrm{Li}$ & 0.0388 & 0.0313 & 0.0374 & 0.3286 & 1.0000 & 1.0000 & 1.0000 \\
\hline $\mathrm{Mg}$ & 0.0060 & 0.4253 & 0.0150 & 0.0266 & 0.4701 & 0.5083 & 1.0000 \\
\hline $\mathrm{Mn}$ & 0.0036 & 0.3468 & 0.0070 & 1.0000 & 0.2959 & 1.0000 & 0.6964 \\
\hline $\mathrm{Na}$ & 0.0242 & 0.1985 & 0.0173 & 0.1525 & 1.0000 & 1.0000 & 1.0000 \\
\hline $\mathrm{SiO}$ & 0.0686 & 0.0660 & 0.0675 & 0.3156 & 1.0000 & 1.0000 & 1.0000 \\
\hline $\mathrm{Sr}$ & 0.0223 & 0.1860 & 0.0146 & 0.3852 & 1.0000 & 1.0000 & 1.0000 \\
\hline $\mathrm{Cl}$ & 0.0456 & 0.5588 & 0.0694 & 0.1427 & 0.8493 & 1.0000 & 1.0000 \\
\hline $\mathrm{Br}$ & 0.0319 & 0.6030 & 0.0778 & 0.0684 & 0.8568 & 0.6901 & 1.0000 \\
\hline
\end{tabular}

In gray indicated $p$ value less than 0.05 , which means statistically significant 
Table 3 Comparison of descriptive statistic of full dataset versus representative dataset

\begin{tabular}{|c|c|c|c|c|c|c|c|c|c|c|c|c|}
\hline 1 & 2 & & & & 3 & & & & 4 & & & \\
\hline \multirow[t]{2}{*}{ Parameter } & \multicolumn{4}{|c|}{ Characteristics of the complete set (40 samples) } & \multicolumn{4}{|c|}{ Characteristics of the a representative set ( 37 samples) } & \multicolumn{4}{|c|}{ Change in characteristics } \\
\hline & Min & Max & Mean & Median & Min & Max & Mean & Median & Min & Max & Mean & Median \\
\hline TDS & 20,182 & 123,815 & 82,270 & 77,424 & 20,182 & 123,815 & 82,270 & 77,424 & 0 & 0 & 0 & 0 \\
\hline $\mathrm{Cl}$ & 4100 & 79,000 & 48,440 & 47,750 & 12,000 & 79,000 & 51,593 & 50,000 & 7900 & 0 & 3153 & 2250 \\
\hline $\mathrm{Na}$ & 215 & 28,750 & 19,232 & 22,229 & 4017 & 28,750 & 20,670 & 22,439 & 3802 & 0 & 1438 & 210 \\
\hline $\mathrm{Ca}$ & 62 & 11,712 & 5543 & 6036 & 1400 & 11,712 & 5968 & 6308 & 1338 & 0 & 425 & 272 \\
\hline $\mathrm{K}$ & 82 & 10,240 & 1422 & 529 & 228 & 7040 & 1255 & 536 & 146 & -3200 & -167 & 8 \\
\hline $\mathrm{Ba}$ & 0.2 & 1710 & 368.0 & 114.8 & 5.4 & 1710 & 397.4 & 127.2 & 5.2 & 0 & 29.4 & 12.4 \\
\hline $\mathrm{Br}$ & 25.0 & 1100 & 533.9 & 585.0 & 100.0 & 1100 & 569.7 & 617.5 & 75 & 0 & 35.8 & 32.5 \\
\hline $\mathrm{Fe}$ & 0.5 & 105.0 & 33.1 & 28.5 & 0.5 & 105.0 & 34.2 & 30.0 & 0 & 0 & 1.2 & 1.5 \\
\hline $\mathrm{Sr}$ & 0.2 & 2230 & 870.1 & 851.5 & 106.0 & 2230 & 938.7 & 857.0 & 105.9 & 0 & 68.6 & 5.5 \\
\hline $\mathrm{Li}$ & 0.1 & 28.9 & 12.5 & 12.2 & 1.5 & 28.9 & 13.5 & 12.5 & 1.4 & 0 & 1.0 & 0.3 \\
\hline
\end{tabular}

a few percent in relation to the full set. In the case of TDS, no changes were made, because (coincidentally) in three samples considered unrepresentative, this parameter was not determined. The inclusion of unrepresentative samples underestimates the minimum performance levels. The minima of both sets do not differ in the case of iron concentration, while in the case of other parameters, the differences are significant: for chloride and potassium concentrations, the minimum values are three times higher, and for bromide concentrations, four times higher; for sodium, calcium, barium, and lithium, the difference is at least an order of magnitude, and for strontium, it is almost 3 orders of magnitude.

\section{Comparison of the chemical composition of flowback fluids from Poland and worldwide localizations}

According to the data presented, flowback fluids from different regions of the world vary a lot in their chemical composition (a large range of values for individual analyzed parameters). The differences and similarities of ranges of physicochemical parameters of flowback fluids are shown in Table 4 and presented in graphs (Fig. 7).

Except for flowback fluids from Canada, the $\mathrm{pH}$ values of the fluids were close to neutral. Canadian flowback's $\mathrm{pH}$ represented a wide range from acidic to alkaline. The highest concentration of TDS above $200,000 \mathrm{mg} / \mathrm{l}$ was observed in flowback fluids from the USA (Marcellus), Canada, and the UK. The concentration of TDS in the fluids from China was almost four times lower compared to those mentioned earlier.

All fluids were characterized by high salinity, though their values differed significantly. Similar ranges were observed in European fluids (Germany and the UK); however, in the case of Poland, the minimum observed value was four times lower than that for fluids from other locations.

In all fluids, the high concentration of calcium and sodium was observed. The highest concentration of sodium was found in fluids from the Marcellus deposit in the USA and Canada, whereas the lowest concentration was found in the fluids from Poland, China, and Barnett deposit in the USA. The

Table 4 Comparison of chemical characteristics of flowback fluid from different regions of the world

\begin{tabular}{|c|c|c|c|c|c|c|c|c|}
\hline & USA & USA & Canada & China & China & Germany & UK & Poland \\
\hline Parameter & Marcellus & Barnett & & Longmaxi & Tarim Basin & & & \\
\hline $\mathrm{pH}$ & $4.9-7.9$ & $6.5-8.0$ & $2.3-9.5$ & $6.84-7.48$ & $5.86-6.71$ & $\mathrm{nr}$ & $\mathrm{nr}$ & $5.66-8.14$ \\
\hline TDS & $680-261,000$ & $5850-97,000$ & $3609-228,259$ & $13,000-60,000$ & $\mathrm{nr}$ & $\mathrm{nr}$ & $94,000-210,000$ & $20,182-123,815$ \\
\hline $\mathrm{Cl}$ & $64.2-181,000$ & $3300-60,800$ & $1893-164,018$ & $13,110-36,470$ & $32,000-64,000$ & $40,360-88,440$ & $48,000-100,000$ & $12,000-79,000$ \\
\hline $\mathrm{Na}$ & $63.8-73,800$ & $278-28,200$ & $1344-51,027$ & $8296-19,830$ & $\mathrm{nr}$ & $17,690-36,390$ & $9300-34,800$ & $4017-28,750$ \\
\hline $\mathrm{Ca}$ & $35.2-24,000$ & $13-6730$ & $13-11,705$ & $564-3870$ & $\mathrm{nr}$ & $6700-16,550$ & $\mathrm{nr}$ & $1400-11,712$ \\
\hline $\mathrm{K}$ & $2.69-3950$ & $4-750$ & $49-1920$ & $157-768$ & $\mathrm{nr}$ & $52-157$ & $28.8-40.6$ & $228-7040$ \\
\hline $\mathrm{Ba}$ & $0.33-4220$ & $0.05-17.9$ & $<1-467$ & $138-412$ & $\mathrm{nr}$ & $180-593$ & $9.20-30.0$ & $5-1710$ \\
\hline $\mathrm{Br}$ & $15.8-1600$ & $34.3-798$ & $2.1-38$ & $180-470$ & $\mathrm{nr}$ & $\mathrm{nr}$ & $\mathrm{nr}$ & $100-1100$ \\
\hline $\mathrm{Fe}$ & $2.68-158$ & nd-93.80 & $\mathrm{nr}$ & $7-62$ & $\mathrm{nr}$ & $23-160$ & $4.20-23$ & $<1-105$ \\
\hline $\mathrm{Sr}$ & $0.58-8020$ & nd-1550 & $3.7-1263$ & $67-320$ & $\mathrm{nr}$ & $790-1720$ & $\mathrm{nr}$ & $106-2230$ \\
\hline $\mathrm{Li}$ & $4.06-137$ & $0.05-10.80$ & $<1-49$ & $\mathrm{nr}$ & $\mathrm{nr}$ & $5-6$ & $\mathrm{nr}$ & $1.46-28.9$ \\
\hline
\end{tabular}

$n d$, not detected; $n r$, not reported 
concentration of calcium was the highest in the fluids from the Marcellus deposit in the USA and from Germany. The lowest concentration of calcium was observed in flowback fluids from China. In Poland and Canada, calcium concentrations were very similar.
The concentration of potassium was lower than sodium and calcium, and its highest values were observed in Poland. The highest concentration of barium was determined in fluids from the Marcellus deposit in the USA, whereas the lowest in fluids from Barnett deposit also in the USA and in the UK. The lowest
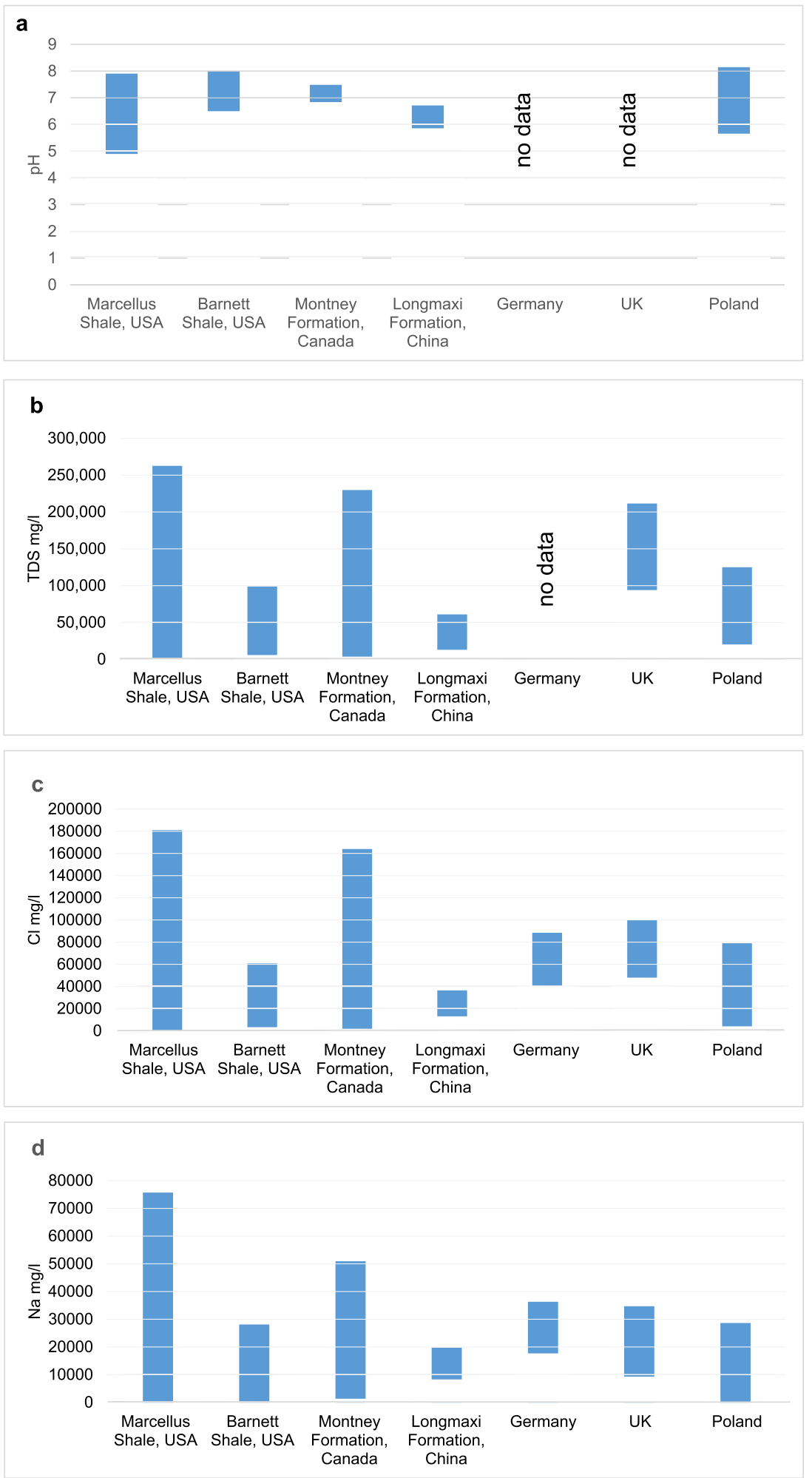

Fig. 7 a-k Comparison of flowback characteristics in different regions 

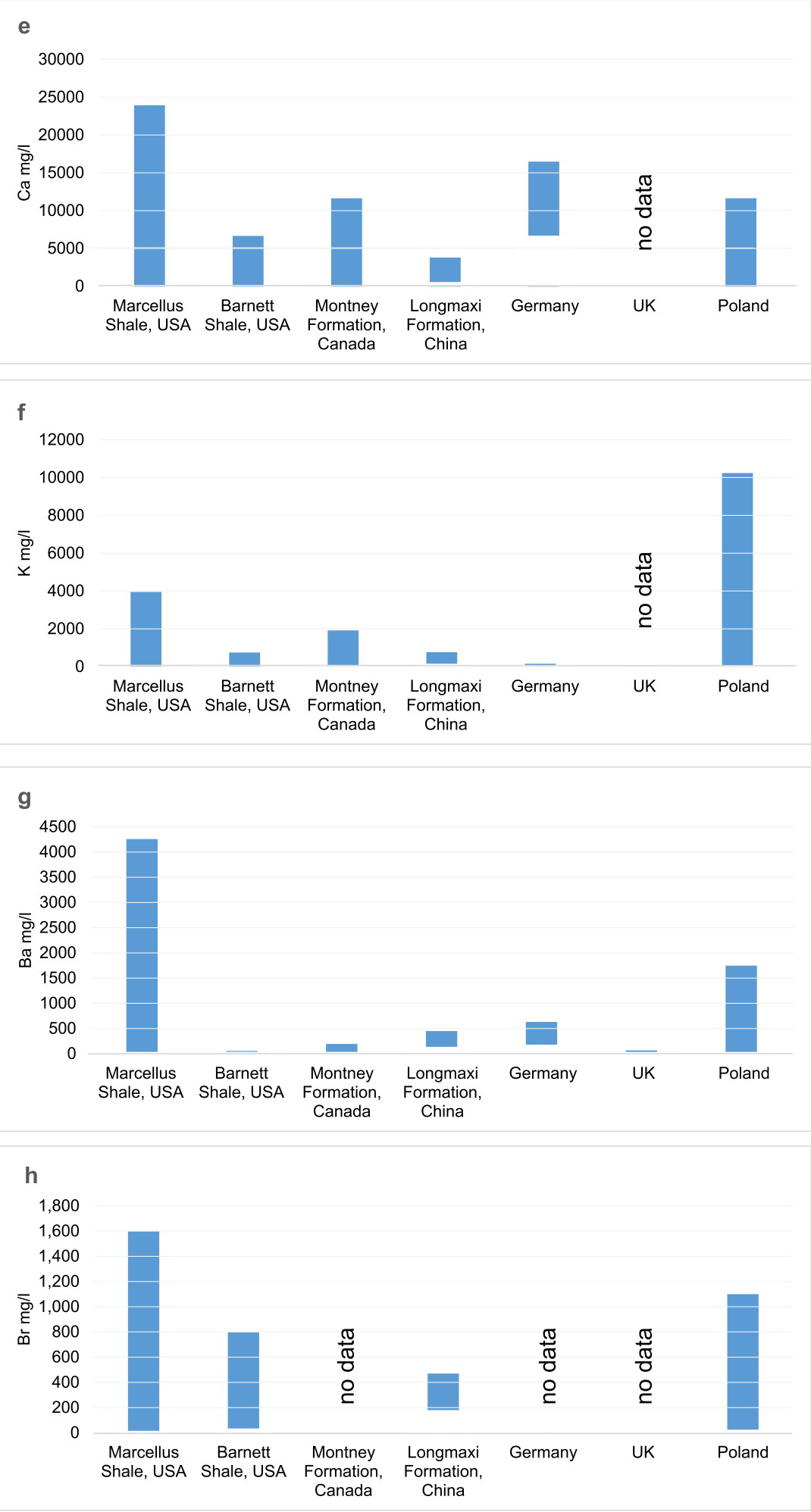

Fig. 7 (continued)

concentration of bromide was observed in Canadian flowback fluids.

The highest concentration of iron was observed in flowback fluids from the Marcellus deposit and from
Germany. In Poland and China, iron was present at lower level, being the lowest in flowback analyzed in the UK. 

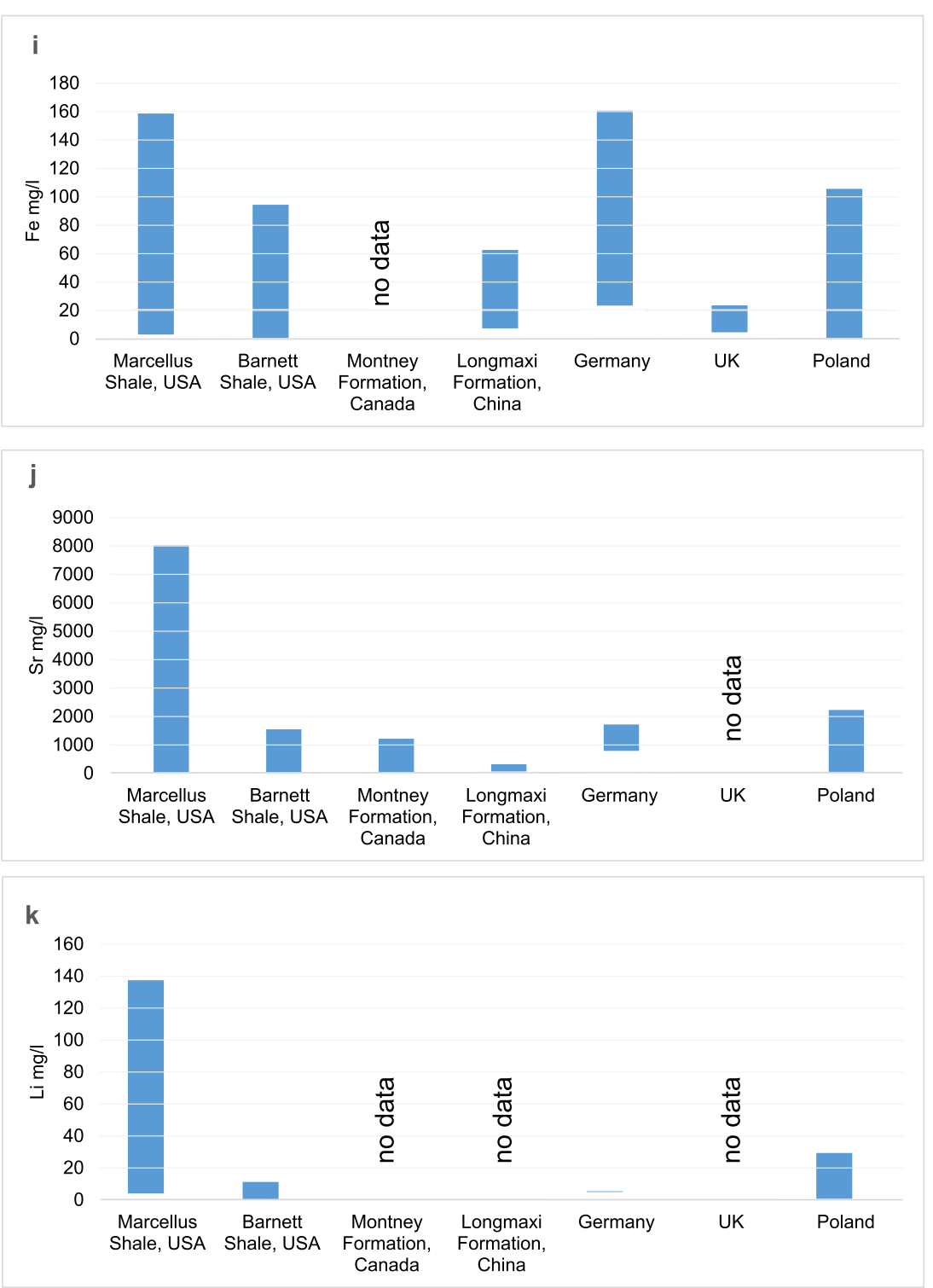

Fig. 7 (continued)

Strontium and lithium were most abundant in flowback fluids from the Marcellus deposit. The lowest concentration of lithium was detected in samples from Germany.

The values of other tested parameters were generally diverse; however, for individual sedimentation basins, higher values of some parameters were identified as a specific feature of the region. It is important to note that the concentration of sulfate was low in all tested flowback fluids. In the Polish flowback fluids in almost $90 \%$ of samples, this parameter was not detected above the LoQ of the testing method.

\section{The possibilities of flowback fluids management}

The variability of the chemical composition of flowback fluids influences the proper way of their management.
The principles of management of flowback fluids are defined by the European Union law - the Directive on the management of waste from extractive industries and also the Directive of waste (in the scope not covered by the Directive on the management of waste from extractive industries). According to this law, the flowback fluids are classified as mining waste produced during ore and other minerals processing and belong to a group named other not listed waste with code number 010599 . The use of methods aimed at preventing the generation of extractive waste is required. If it is not possible to prevent waste generation, the mining waste should be recovered and eventually disposed of (including depositing in a waste facility).

Flowback fluid should be preferably reused. Otherwise, it is directed to a treatment plant (including wastewater 
treatment plant) or a waste facility (Directive 2006/21/EC of the European Parliament and of the Council of 15 March 2006).

In terms of technology, there are several methods for flowback fluids treatment reported in the literature (Olsson et al. 2013; Konieczyńska et al. 2016-unpublished; Butkovskyi et al. 2018; Sun et al. 2019). The preliminary treatment methods frequently used for the removal of suspended solids and heavy metals are sedimentation, filtration, flotation, and coagulation. Oxidation and adsorption on granulated activated carbon are used for the removal of organic substances. Removal of dissolved solid is usually performed by evaporation and crystallization and also with membrane processes such as reverse osmosis and nanofiltration (Olsson et al. 2013). Ion exchange processes may be also applied for the removal of dissolved salt. During treatment processes, some valuable elements could be recovered from flowback fluids (Konieczyńska et al. 2016 unpublished).

In order to sustain the effectiveness of any recovery process of the flowback fluid, its chemical composition stability over time should be controlled based on selected indicators. In case of flowback fluids from Poland, the treatment processes have to be tailored to the following concentration ranges: TDS from 20 to $124 \mathrm{~g} / 1, \mathrm{Cl}^{-}$from 12 to $80 \mathrm{~g} / 1, \mathrm{Na}^{+}$from 4 to $30 \mathrm{~g} / \mathrm{l}, \mathrm{Ca}^{2+}$ from 1 to $12 \mathrm{~g} / \mathrm{l}, \mathrm{K}^{+}$from 200 to $7500 \mathrm{mg} / \mathrm{l}, \mathrm{Ba}^{2+}$ from 5 to $1800 \mathrm{mg} / \mathrm{l}, \mathrm{Br}^{-}$from 100 to $1100 \mathrm{mg} / \mathrm{l}, \mathrm{Fe}^{2+, 3+}$ from 0 to 105 $\mathrm{mg} / \mathrm{l}, \mathrm{Sr}^{+}$from 100 to $2500 \mathrm{mg} / \mathrm{l}$, and $\mathrm{Li}^{+}$from 0 to $30 \mathrm{mg} / \mathrm{l}$.

The methods of flowback fluids treatment in Poland complies with the requirements outlined in the Directive on management of waste from extractive industries and with the Polish legal framework. Flowback fluids can be recovered or disposed of (in an installation) or stored (in a mining waste facility). The appropriate permits and decisions on the processing and storage are required for both installation and facility. Also, the transferred fluids should meet the requirements in terms of compliance of their chemical composition with the chemical composition presented in these permits and decisions. Additionally, a person providing flowback fluids (the holder and/or producer of waste) should have a mining waste management program, which indicates that this waste may be recovered (or stored) by processes addressed in the permits. The underground storage of flowback is possible under the procedure of permitting and is limited to other than hazardous and inert mining waste.

The appropriate management of large volumes of liquid waste reduces the risk for people and for environment losses.

\section{Conclusions}

The flowback fluids are characterized by high salinity, caused mainly by high concentrations of chloride, sodium, calcium, and potassium. The high concentrations of barium, bromide, strontium, lithium, and iron were also found in flowback fluids. The composition of flowback fluids varied between geographical locations and also because of different technologies used for hydraulic fracturing and completion treatments.

In case of flowback fluids from Poland, they are characterized by TDS in the range from 20,182 to $123,815 \mathrm{mg} / 1$, chloride from 12,000 to $79,000 \mathrm{mg} / \mathrm{l}$, sodium from 4017 to 28,750 $\mathrm{mg} / \mathrm{l}$, calcium 1400 to $11,712 \mathrm{mg} / \mathrm{l}$, potassium from 228 to $7040 \mathrm{mg} / \mathrm{l}$, barium from 5.4 to $1710 \mathrm{mg} / \mathrm{l}$, bromide from 100 to $1100 \mathrm{mg} / 1$, iron from 0.5 to $105 \mathrm{mg} / \mathrm{l}$, strontium 106 to 2230 $\mathrm{mg} / \mathrm{l}$, and lithium from 1.5 to $28.9 \mathrm{mg} / 1$.

Statistical analyses revealed a relation between sampling schedule and the following parameters: electrical conductivity concentration of ammonia, boron, barium, calcium, lithium, magnesium, manganese, sodium, strontium, chloride, bromide, and silica. On the contrary, the $\mathrm{pH}$ and concentration of potassium and iron were irrespective of the sampling schedule (meaning time and spot of sample collection).

The diversity of the characteristics of flowback fluids is the main factor that determines the selection of a waste management method. Due to the presented variability of the chemical composition of flowback over time, it is recommended to monitor the composition by continuous measurements of selected indicators during the whole treatment process. This contributes to proper and safe handling especially in the case of exploration wells in new regions. Such monitoring ensures the technical safety of the installation neutralizing this type of waste and prevent from exceeding any threshold values of the parameters permitted for a given treatment measure.

In the case of waste characterized by high variability of chemical composition over time, the general rule for determining properties before the management should include the appropriate selection of the sampling site so that the obtained results present unified average parameters readings and not random "peaks or valleys" of values.

Author contribution All authors contributed to the study's conception and design. Material preparation, data collection, and analysis were performed by Joanna Fajfer and Olga Lipińska with the support Monika Konieczyńska. The statistical analysis was prepared by Olga Lipińska. The first draft of the manuscript was written by Joanna Fajfer, Olga Lipińska, and Monika Konieczyńska. The final revision of the first draft was made by Monika Konieczyńska. All authors commented on previous versions of the manuscript. Revision of the final manuscript was done by Joanna Fajfer and Monika Konieczyńska. All authors read and approved the final manuscript.

Funding The article was prepared based on data collected within projects which received funding from the Polish National Fund for Environmental Protection and Water Management, the Polish National Centre for Research and Development, and European Union's Horizon 2020 research and innovation. The final editorial work was supported by the PGI-NRI statutory funds (Project No. 62.9012.1978.00.0).

Data availability The datasets used and/or analyzed during the current study are available from the authors on reasonable request. 


\section{Declarations}

Ethics approval and consent to participate Not applicable.

\section{Consent for publication Not applicable.}

Competing interests The authors declare no competing interests.

Open Access This article is licensed under a Creative Commons Attribution 4.0 International License, which permits use, sharing, adaptation, distribution and reproduction in any medium or format, as long as you give appropriate credit to the original author(s) and the source, provide a link to the Creative Commons licence, and indicate if changes were made. The images or other third party material in this article are included in the article's Creative Commons licence, unless indicated otherwise in a credit line to the material. If material is not included in the article's Creative Commons licence and your intended use is not permitted by statutory regulation or exceeds the permitted use, you will need to obtain permission directly from the copyright holder. To view a copy of this licence, visit http://creativecommons.org/licenses/by/4.0/.

\section{References}

Balashov VN, Engelder T, Gu X, Fantle MS, Brantley SN (2015) A model describing flowback chemistry changes with time after Marcellus Shale hydraulic fracturing. The American Association of Petroleum Geologists 99:143-154. https://doi.org/10.1306/ 06041413119

Bergman A, Weber FA, Meiners G, Müller F (2014) Potential waterrelated environmental risks of hydraulic fracturing employed in exploration and exploitation of unconventional natural gas reservoirs in Germany. Environmental Sciences Europe 26. https://doi.org/10. $1186 / 2190-4715-26-10$

Busby J (2018) Fracking wastewater. http://www.after-oil.co.uk/ fracking wastewater.htm. Accessed 01 Apr 2020

Bustin MR, Owen J, Bustin A (2018) Insights into reservoir dynamics of the Montney Formation from analysis of flowback and produced fluids, petrophysics, and fluid compatibility modeling. Abstract. AAPG International Conference and Exhibition, Cape Town, South Africa, http://www.searchanddiscovery.com/abstracts/html/ 2018/ice2018/abstracts/2997006.html- Accessed: 01 April 2020

Butkovskyi A, Cirkel G, Bozileva E, Bruning H, Van Wezel AP, Rijnaarts HHM (2018) Estimation of the water cycle related to shale gas production under high data uncertainties: Dutch perspective. Journal of Environmental Management. 231:483-493. https://doi. org/10.1016/j.jenvman.2018.10.066

Changbo C, Pieńkowski G (2015) Shale gas in China - how much and when? Przegląd Geologiczny 63:1206-1214

Curtis JB (2002) Fractured shale-gas systems. AAPG Bulletin 86(11): $1921-1923$

Directive 2006/21/EC of the European Parliament and of the Council of 15 March 2006 on the management of waste from extractive industries and amending Directive 2004/35/EC - statement by the European Parliament, the Council and the Commission Official Journal of the European Union L 102/15

Dyrka I (2013) Petrophysical properties of shale rocks in: shale gas as seen by Polish Geological Survey. PGI-NRI. Warsaw. pp 44-47

EA (2011) Shale gas north west - monitoring of flowback water. https:// www.whatdotheyknow.com/request/292030/response/803793/ attach $/ \mathrm{html} / 3 / 6$ th\%20Dec\%20Shale\%20gas\%20North\%20West\% 20Monitoring\% $\%$ of $\% 20$ flowback $\% 20$ water\%20update....pdf.html Accessed: 1 April 2020
Fajfer J, Lipińska O, Konieczyńska M (2016) Flowback fluids treatment technology with water recycling and valuable metals recovery. Conference Proceedings. Paris. France. Feb.22-23.2016. 18(2) Part XI. p:1564-1568.

Gauthier TG (2001) Detecting trends using Spearman's rank correlation coefficient. Environmental Forensics DOI 2:359-362. https://doi. org/10.1080/713848278

Haluszczak LO, Rose AW, Kump LR (2013) Geochemical evaluation of flowback brine from Marcellus gas wells in Pennsylvania, USA. Appl. Geochem. 28:55-61. https://doi.org/10.1016/j.apgeochem. 2012.10.002

Hammond GP, O'Grady Á, Packham DE (2015) Energy technology assessment of shale gas 'fracking' - a UK perspective. Energy Procedia. 75:2764-2771. https://doi.org/10.1016/j.egypro.2015.07. 526

Harrison G, Parkinson S, McFarlane G (2014) Shale gas and fracking: examining the evidence. Scientists for Global Responsibility (SGR) and the Chartered Institute of Environmental Health (CIEH)https:// www.sgr.org.uk/sites/sgr.org.uk/files/SGR-CIEH-Shale-gas-bfg. pdf

Hayes T (2012) Barnett and Appalachian shale water management and reuse technologies, Gas Technology Institute, the Research Partnership to Secure Energy for America, RPSEA: https://www. netl.doe.gov/file\%20library/research/oil-gas/Natural\%20Gas/ shale\%20gas/08122-05-final-report.pdf- Accessed: 10 December 2019

He C, Zhang T, Vidic RD (2013) Use of abandoned mine drainage for the development of unconventional gas resources. Disruptive Science and Technology 1(4):176. https://doi.org/10.1089/dst.2013.0014

Jacobsen OS, Gravesen P (2016) Handling fracking fluids and flowback for shale gas. M4 Shale Gas - D8.2. https://www.m4shalegas.eu/ downloads/M4ShaleGas\%20-\%20D8.2\%20-\%20Handling\% 20 fracking $\% 20$ fluids $\% 20$ and $\% 20$ flowback $\% 20$ for $\% 20$ shale $\%$ 20gas\%20-\%20September\%202016.pdf Accessed: 01 April 2020

Janas M, Dyrka I (2013) US and European shale plays in: shale gas as seen by Polish Geological Survey. PGI-NRI. Warsaw. pp 58-65

Jarvie D M, (2012) Shale resource systems for oil and gas: part 1-shalegas resource systems in: shale reservoirs - giant resources for the 21st century: AAPG Memoir 97, p. 69-87

Kantor M, Konieczyńska M, Lipińska O (2015) Shale gas exploration the results of environmental field studies. Przeglad Geologiczny 63: 404-409 (in Polish)

Karcz P, Janas M, Dyrka I (2013) Polish shale gas deposits in relation to selected shale gas perspective areas of Central and Eastern Europe. Przegląd Geologiczny 61:411-423 (in Polish)

Kondash A et al (2017) Quantity of flowback and produced waters from unconventional oil and gas exploration. Science of the Total Environment. 574:314-321. https://doi.org/10.1016/j.scitotenv. 2016.09.069

Konieczyńska et al. (2011) Environmental aspects of the hydraulic fracturing process carried out in the Łebien LE-2H well. Final report (in Polish) https://www.pgi.gov.pl/en/dokumenty-pig-pib-all/kopalniawiedzy/gaz-lupkowy/786-the-lebien-report/file.html

Konieczyńska $\mathrm{M}$ et al. (2015) The environment and shale gas exploration. Results of studies on the soil- water environment, ambient air, acoustic climate, process fluids and wastes. Published by Directorate General for Environmental Protection, http:/www.gdos.gov.pl/ files/artykuly/38173/The_environment_and_shale_gas exploration_RESULTS_OF_STUDIES_ON_THE_SOIL_ WATER ENVIRONMENTT AMBIENT AIR ACOÜSTIC CLIMATE_PROCESS_FLUIDS_AND_WASTES.pdf

Konieczyńska M. et al., (2016) Technology for the recovery of valuable metals from post-treatment fluids, generated by hydraulic fracturing of gas-bearing shale, with the requirement of water reuse. PyrogasICHTJ-PIG-PIB Consortium, Conspan-Bluegas Project. 2016, unpublished 
Krogulec E, Sawicka K (2012) Model analysis of chemistry transformation of the technological fluids used in obtaining gas from shale (shale gas). Biuletyn Państwowego Instytutu Geologicznego 451: 161-168 (in Polish)

Kruskal WH (1952) A nonparametric test for the several sample problem. In Mathematics Sat 23:525-540

Kuwayama Y, Olmstead S, Krupnick A (2015) Water quality and quantity impacts of hydraulic fracturing. Curr Sustainable Renewable Energy Rep. 2:17-24. https://doi.org/10.1007/s40518-014-0023-4

Liang T, Shao L, Yao E, Zuo J, Liu X, Zhang B, Zhou F (2018) Study on fluid-rock interaction and reuse of flowback fluid for gel fracturing in desert area. Geofluid. 2018:1-9. https://doi.org/10.1155/2018/ 8948961

Ministry of the Environment (2016) Shale Gas in Poland. Prospecting and exploration 2007-2016 (as of 29 February 2016). https://infolupki. pgi.gov.pl/sites/default/files/czytelnia_pliki/shale-gas-in-polandprospecting-and-exploration-2007-2016.pdf. Accessed 03 Aug 2020

Monaghan AA (2014) The Carboniferous shales of the Midland Valley of Scotland: geology and resource estimation. British Geological Survey for Department of Energy and Climate Change, London, UK. https://assets.publishing.service.gov.uk/government/uploads/ system/uploads/attachment_data/file/360471/BGS_DECC_MVS_ 2014 MAIN REPORT.pdf

Oetjen K, Giddings CGS, McLaughlin M, Nell M, Blotevogel J, Helbling DE, Mueller D, Higgins CP (2017) Emerging analytical methods for the characterization and quantification of organic contaminants in flowback and produced water. Trends in Environmental Analytical Chemistry. https://doi.org/10.1016/j.teac.2017.07.002

Olmstead SM, Muehlenbachs L, Shih J, Chu Z, Krupnick AJ (2013) Shale gas development impacts on surface water quality in Pennsylvania. Proceedings of the National Academy of Sciences 110:110-4967. https://doi.org/10.1073/pnas.1213871110

Olsson O, Weichgrebe D, Rosenwinkel KH (2013) Hydraulic fracturing wastewater in Germany: composition, treatment, concerns. Environ Earth Sci. 70:3895-3906. https://doi.org/10.1007/s12665-013$2535-4$

Owen J (2017) An investigation into the controls and variability of the flowback water inorganic geochemistry of the Montney Formation, northeastern British Columbia and northwestern Alberta, Canada. Dissertation. The University of British Columbia. Dissertation. https://open.library.ubc.ca/cIRcle/collections/ubctheses/24/items/1. 0362574 Accessed: 03 January 2020

Owen J, Bustin MR (2017) Implications of the inorganic geochemistry of flowback water from the Montney Formation, northeastern British Columbia and northwestern Alberta: progress report in: Geoscience BC Summary of Activities 2016. Geoscience BC, Report 2017-1: 49-54 http://cdn.geosciencebc.com/pdf/SummaryofActivities2016/ SoA2016_Owen.pdf

Pakulska D (2015) Chemical hazards arising from shale gas extraction. Medycyna Pracy 66(1):99-117 (in Polish). https://doi.org/10. $13075 / \mathrm{mp} .5893 .00147$

Poprawa P (2010a) Shale gas hydrocarbon system - North American experience and European potential. Przegląd Geologiczny 58:216225 (in Polish)

Poprawa P (2010b) Shale gas potential of the Lower Palaeozoic complex in the Baltic and Lublin-Podlasie basins (Poland). Przegląd Geologiczny 58:226-249 (in Polish)
Pripch G, Coulon F, Anthony EJ (2015) Review of the scientific evidence to support environmental risk assessment of shale gas development in the UK. Science of The Total Environment 563:731-740. https:// doi.org/10.1016/j.scitotenv.2015.11.026

Rivard C, Lavoie D, Lefebvre R, Séjourné S, Lamontagne C, Duchesne M (2014) An overview of Canadian shale gas production and environmental concerns. Int. J. Coal Geol. 126:64-76. https://doi.org/10. 1016/j.coal.2013.12.004

Siegel S, Castellan NJ Jr (1988) Nonparametric statistics for the behavioral sciences, 2nd edn. McGraw-Hill Book Company, New York

Steliga T, Uliasz M (2012) Selected environmental issues during the exploration, opening up and exploitation of natural gas from shale formations. Nafta-Gaz 5:273-283 (in Polish)

Stephenson MH (2015) Shale gas in North America and Europe. Energy Sciences\&Engineering. 4:4-13. https://doi.org/10.1002/ese3.96

Stumford L, Azapagic A (2014) Life cycle environmental impacts of UK shale gas. Applied Energy. 134:506-518. https://doi.org/10.1016/j. apenergy.2014.08.063

Sun Y, Wang D, Tsang DCW, Wang L, Ok YS, Feng Y (2019) A critical review of risks, characteristics, and treatment strategies for potentially toxic elements in wastewater from shale gas extraction. Environment International. 125:452-469. https://doi.org/10.1016/j. envint.2019.02.019

U.S. EPA (2016) Hydraulic fracturing for oil and gas: impacts from the hydraulic fracturing water cycle on drinking water resources in the United States (Final Report). U.S. Environmental Protection Agency, Washington, DC, EPA/600/R-16/236F. www.epa.gov/ hfstudy. Accessed:01 December 2019

Vengosh A, Jackson RB, Warner N, Darrah TH, Kondash A (2014) A critical review of risks to water resources from unconventional shale gas development and hydraulic fracturing in the United States. Environmental Science and Technology 48:8334-8348. https://doi. org/10.1021/es405118y

Vieth-Hillebrand A, Wilke FDH, Schmid FE, Munder W, Zhu Y, Francu J (2017) Characterizing the variability in chemical composition of flowback water - results from laboratory studies. Energy Procedia. 125:136-144. https://doi.org/10.1016/j.egypro.2017.08.146

Yang B, Zhang H, Kang Y, You L, She J, Wang K, Chen Z (2019) In situ sequestration of a hydraulic fracturing fluid in Longmaxi shale gas formation in the Sichuan Basin. Energy Fuels DOI 33:6983-6994. https://doi.org/10.1021/acs.energyfuels.9b00712

Zambrano L, Pedersen PK, Aguilera R (2016) Geologic controls on gas production and hydraulic-fracturing flowback in tight gas sandstones of the Late Jurassic Monteith Formation, Deep Basin, Alberta, Canada. Society of Petroleum Engineers. 19:024-040. https://doi.org/10.2118/167177-PA

Zhou C, Dong D, Wang Y, Li X, Huang J, Wang S, Guan Q, Zhang C, Wang H, Liu H, Bai W, Liang F, Lin W, Zhao Q, Liu D, Yang Z, Liang P, Sun S, Qiu Z (2016) Shale gas in China: characteristics, challenges and prospects (II). Petrol. Explor. Develop. 43(2):182196

Zolfaghari A, Tang A, Holyk J, Binazadeh M, Dehghanpour H, Bearinger D (2015) Chemical analysis of flowback water and downhole gas shale samples. Society of Petroleum Engineers https://www. researchgate.net/publication/301415916

Publisher's note Springer Nature remains neutral with regard to jurisdictional claims in published maps and institutional affiliations. 